\title{
SOME MISCELLANEOUS NOVELTIES IN THE NEW CORPORATION STATUTES
}

\author{
Euvin R. LatTy* \\ INTRODUCTION
}

The recent wave of revisions of the general business corporation statutes of many jurisdictions has typically introduced many changes that, while novel, perhaps, in their own particular contexts, are not at all revolutionary in American legislative history. Although examples abound, an apposite illustration are the newly-popular provisions relating to the maintenance and inspection of records: ${ }^{1}$ there is practically nothing here that cannot be found somewhere in the corporate legislation enacted in this country during the first third of the present century. This is not to say, of course, that the current statutory revisions have produced no innovations-for, indeed, they have. Most of the more significant of these have, in fact, been explored in some detail elsewhere in this symposium. Accordingly, it is to a collection and discussion-although by no means an exhaustive one $e^{2}$-of some odds and ends that remain that this article is devoted.

By "new" corporation statutes, reference is made to those enacted in the r940's and 1950's. This may, perhaps, be a rather arbitrary criterion, but it would seem, at least partially, to be indicated by the post-World-War-II ferment in the area of corporate legislation; moreover, it fits the midcentury outlook of this symposium. It need hardly be noted, however, that the extensive revisions of corporation statutes in the early I930's-to which may be added, for good measure, the Ohio and Delaware revisions of the late I920's-also introduced many new features; and the famous New Jersey corporation statute of 1896 , which to a legal historian at least is recent legislation and which, it may be hazarded, is the fountainhead of modern American corporation law, was daringly unique in a number of respects.

\section{I}

\section{Organization and Related Early-Stage Matters}

\section{Corporate name}

Perhaps the most significant novelty in organizational stage is the right given by the new statutes of Oregon, Texas, and Virginia, following the Model Business

- B.S. 1923, Bowdoin College; J.D. I930, University of Michigan; J.Sc.D. 1936, Columbia University. Member of the New York bar; Dean and Professor of Law, Duke University. Author, Subsidiaries and Affiliated Corporations (1936), Introduction to Business Assoctatrons (1951). Contributor to legal periodicals.

${ }^{1}$ E.g., N.C. Gen. Stat. \$ 55-38 (Supp. I955); N.D. Laws 1957, c. ro2, \$ 47; OrE. Rev. Stat. 57.246 (Supp. I955); and TEx. Bus. Corp. Act art. 2.44 (1956).

A significant, but unsuspected, innovation may sometimes be effected, intentionally or otherwise, by an apparently innocent and minor change in a statutory text that is superficially quite orthodox. An 
Corporation Act, to a foreign corporation not doing business in the state to "register" its name and to renew this registration from year to year. ${ }^{3}$ This enables the "fencing in" of a name, if it is still open, which makes it unavailable even to local enterprises, in the event that the registrant should, in the future, expand its activities into the state and wish to use the name. This feature was not adopted in the District of Columbia, North Carolina, North Dakota, and Wisconsin, however, even though recent statutory revisions in those jurisdictions otherwise closely followed the Model Act's provisions relating to corporate names. Of course, even in jurisdictions not following the Model Act in this respect, a foreign corporation can still "fence in" its name, if it is still open, by forming and maintaining therein a subsidiary corporation; but this procedure is more expensive and cumbersome. The ultimate issue, then, is whether "fencing in" should be made cheaper and easier.

A 1957 Pennsylvania enactment authorizes the use of an injunction to prevent a corporation from using a name which it has agreed to give up, or a name deceptively similar, under a written consent duly executed and filed."

A few recent statutes also make it clear that the choice of an official corporate name does not prevent the adoption of an assumed name as well. 5 Thus, for example, a corporation with the legal name of Smith Motor Repairs Co., Inc., might quite properly wish and be permitted to do business under the name of West Side Garage.

\section{Single incorporator}

Wisconsin's 1951 statutory revision admits of a single incorporator, instead of requiring the customary three or more. ${ }^{6}$ This is not an entirely new idea, ${ }^{7}$ but it is so rare as to merit notice. A more general adoption of this provision, however, can perhaps be anticipated in view of the apprehension aroused in one state recently by a decision that questioned the validity of a one-man corporation under the usual statutory provision requiring three or more incorporators. ${ }^{8}$

\section{Simplified incorporation procedure-single registry and little else}

The Model Act would streamline the incorporation procedure by having only a single central filing in the office of the secretary of state, dispensing with such additional rituals, found until recently nearly everywhere, as recording in the

\footnotetext{
example of this might be those recent dividend statutes that, at first glance, seem to afford adequatc protection by the "stated capital" cushion, but which, on closer examination, apparently remove all restrictions on the payment of dividends. See infra 374-76.

${ }^{3}$ Ore. Rev. Stat. $\$ 57.055,57.060$ (Supp. 1955); Tex. Bus. Corp. ACt art. 2.07, 2.08 (1956); VA. Code Ann. $\$$ 13.1-8 (Supp. 1956); cf. Model Business Corporatton Act $\$ 8$.

- Pa. Stat. Ann. tit. 15, §\$ 2852-202, 2852-r002 (Supp. 1957).

${ }^{5}$ Ore. Rev. Stat. $\$ 57.045$ (Supp. 1955); TeX. Bus. Corp. Act art. 2.05 (1956).

'WIs. STAT. \$ I80.44 (1955).

TThis unusual feature has long existed in Iowa, see Iowa Code $\$ \$ 673$ et seq., 702 (1850), and persists today. IowA CODE $\$ 491.2$ (1954). The other state with this feature permits the single incorporator to be itself a corporation. Mrch. Comp. Laws $\$ \$ 450.2,450.3$ (r948).

${ }^{8}$ Park Terrace, Inc. v. Phoenix Indemnity Co., 24x N.C. 473 , 85 S.E.2d 677 (1955), on rehearing, 243 N.C. 595, 9x S.E.2d 584 (1956).
} 
central office, filing or recording in a local county seat, submission of papers to other officials for approval, publication in newspapers, opening of books for subscriptions, affidavits of payment of specified percentages of capital stock, and others. ${ }^{9}$ Texas, North Dakota, and Oregon have recently followed the Model Act's streamlining, even as to the single, central filing ${ }^{10}$-Oregon, only after a change of heart in 1955. ${ }^{11}$ Other states that have come under the general influence of the Model Act, however, such as North Carolina, Virginia, and Wisconsin, still require local recording, presumably reflecting the sentiment of the bar. ${ }^{12}$ But it is doubtful whether the infrequent need for a quick inexpensive look at local records, as against getting information from the central office, warrants the additional burden of local recording or even of local duplicate filing.

\section{Pre-incorporation subscriptions and promotional activities}

Although legislation designed to afford a mechanism for creating irrevocable pre-incorporation subscriptions to stock, so as to avoid the pitfalls that legal theory had created for business-like firm commitments, is not novel, ${ }^{13}$ the near unanimity with which corporate law revisions since World War II have adopted the idea is worthy of that designation. ${ }^{14}$

A I95I Oklahoma statutory amendment makes a pre-incorporation subscription revocable if the articles of incorporation are amended by the incorporators without consent of the subscribers. ${ }^{15}$ Apparently the privilege to revoke is absolute, regardless of the seriousness of the amendment, although perhaps a court may take it upon itself to draw distinctions between material and immaterial amendments. ${ }^{16}$

Several novelties relating to subscriptions are also observable in the North Carolina statutory revision of 1955 . This legislation does not recognize as a defense to the enforcement of pre-incorporation subscriptions the failure to notify the subscribers of

${ }^{\circ}$ Model Business Corporation Act $\S 49$. Florida, however, perhaps in response to the spirit of the land boom of the r920's and in reaction to its previous cumbersome requirements, has had a simple, central-filing procedure since 1925. For the rituals previously required in Florida, see Fla. REv. GEN. STAT. $\$ 4051,4052,4054$ (1920).

${ }^{10}$ Tex. Bus. Corp. ACT art. 3.03 (1956); N.D. Laws 1957, c. I02, §50; OrE. REv. Stat. \$ 57-316 (Supp. 1955).

${ }_{12}$ Cf. ORE. REv. $\$ 57-316$, as enacted in Ore. Laws 1953, c. $549, \S 49$.

${ }^{12}$ N.C. Gen. STAT. $\$ \$ 55-4$, 55-8 (Supp. I955); VA. CODE ANN. $\$$ 13.1-5I (Supp. 1956); Wis. Stat. $\$ 180-48$ (1955).

${ }^{13}$ Model Business Corporation Act of 1928, § 6, 9 U.L.A. I32 (I957), provided for irrevocable subscriptions. Legislation pattern thereon still embodies the idea. See LA. REv. STAT. § I2:6 (I950); IDAHO CODE ANN. $\$$ 30-109 (1948); Wash. Rev. CODE $\$ 23.08 .020$ (Supp. 1952).

${ }^{13}$ But irrevocability in the Oklahoma statutory revision of 1947 exists only by implication. See OKLA. Stat. tit. I8, \$ I.3I (195I). Moreover, the Florida statutory revision of I953 is silent on this topic, as is that of Virginia of 1956 . This last, however, has been explained on the ground that under existing judicial decisions, particularly Marcuse v. Broad Grace Arcade Corp., 164 Va. 553, I80 S.E. 327 (1935), subscriptions are revocable only upon unanimous consent of the shareholders and subscribers. See Gibson, The Virginia Corporation Law of 1956, 42 VA. L. Rev, 445, 459 (x956). But one must view the Virginia law as not completely settled, since the Marcuse case involved an attempted cancellation of a subscription duly accepted by the newly-organized corporation and not a pre-incorporation withdrawal by a subscriber.

${ }^{25}$ OkLA. Stat. tit. $\mathrm{r8}, \S \mathrm{I}$.3I(b) and (d) (195I).

${ }^{10} \mathrm{Cf}$. 4 William M. Fletcher, Cyclopedia Corporations $\$$ i 433,1765 (193I). 
their right to participate in selecting the first board of directors or in otherwise perfecting the organization. ${ }^{17}$ It was apparently believed that this defense is used primarily as a convenient excuse to renege on a subscription and that, in real cases of "failure of consideration," where the excluded subscribers had been misled to believe that they would participate in perfecting the organization, a court could still find the exclusion to be a defense. That same legislation also undertakes to regulate in the matter of certain "come on" clauses or representations in connection with subscriptions-e.g., payment to be made out of earnings, subscriber to have "put" option, etc. These features give rise to no defense against the corporation in the enforcement of the subscription, but only to actions against the guilty participants. ${ }^{18}$ Since, however, this provision was apparently inserted for the benefit of innocent interests in the corporation, the absence of such interests might bring about a different result. In addition, this legislation provides a rather unusual alternative remedy against the subscriber who is in default on payments: the corporation is given the choice of rescinding and keeping as liquidated damages up to ten per cent of the subscription price. ${ }^{19}$ Finally, the troublesome common-law distinction between "subscription" and "contract to purchase"20 is sought to be minimized in this legislation by giving the corporation in any event, upon default the rights of enforcement that are normally characteristic of "subscription."21

Promotional activities call to mind the embattled field of promoters' liability for secret profits and overvaluation of property or services received as payment for stock and the related struggles over watered-stock liability. Fortunately, the awkwardness of state law, largely uncodified, which has, perhaps, served only to educate counselors of well-advised promoters as to the finer points of liability avoidance, is less crucial since the Federal Securities Act of $1933 .{ }^{22}$ In any event, a novel exception to the general legislative disposition to leave these matters to the somewhat chaotic common law, with its dubious distinctions and refinements, rendered even more confusing by the advent of the no par value share, is the recent North Carolina statute's endeavor to combine the principles of promoters' liability with those of stock-watering liability, through a new statutorily-defined concept of "watered shares." ${ }^{23}$ The statute adopts the basic idea that when the recipient of shares gets more than that to which he was entitled, in light of both his contribution to the corporation and his relationship to the venture and to those in control, he must either make an additional contribution or surrender some of his shares, whichever be the more appropriate remedy. This approach purports to clarify a number of troublesome points: liability does not turn on whether the diluted outside shareholders

${ }^{17}$ N.C. GEN. StaT. $\$ 55-43(f)$ (Supp. 1955). Cf. Windsor Hotel v. Schenk, 76 W.Va. I, 84 S.E. 9II (I9I5) (absent statute in point).

${ }^{18}$ N.C. Gen. Stat. $\$ 55-43$ (c) (Supp. 1955).

${ }^{10}$ Id. $\$ 55-43$ (i).

${ }^{20}$ Cf. Stern v. Mayer, I66 Minn. 346, 207 N.W. 737 (1926); Annot. 46 A.L.R. I172 (1926).

21 N.C. Gen. STAT. $\$ 55-43$ (a) and (h) (Supp. 1955).

22 48 STAT. 74, I5 U.S.C. \$77 (r952).

${ }^{23}$ N.C. Gen. StAT. \$ 55-53 (Supp. 1955). 
bought their shares directly from the corporation or from the stage-planning promoters nor on whether they were already shareholders when the promoters got their shares or came in later as per the promoters' plan; and liability cannot be evaded by the no par value stock device nor, in all probability, by the issuance of preferred shares to outsiders and watered common shares to the promoters.

\section{Corporate purposes}

A novel and heartening note of realism is found in the Wisconsin statute, which, after setting forth the usual requirement that the charter is to state the purpose for which the corporation is organized, goes on to provide: ${ }^{24}$

It shall be sufficient compliance with this paragraph to state, either alone or with other purposes, that the corporation may engage in any lawful activity within the purposes for which corporations may be organized under this chapter, and all such lawful activities shall by such statement be deemed within the purposes of the corporation, subject to expressed limitations, if any.

Complementing this is a provision, itself not entirely novel, that "it shall not be necessary to set forth in the articles of incorporation any of the corporate powers enumerated in this chapter, ${ }^{, 25}$ which, in turn, is supported by a very broad corporate powers section enumerating an exhaustive list of corporate powers. ${ }^{26}$ Here is a realistic recognition of the fact that today we are ready for a short-charter "allpurpose" corporation-one in which the stockholder has no right to expect management to adhere to enumerated channels of economic activity, but, rather, may well expect management to pursue any line of activity that bids fair to earn an honest dollar. The ancient tradition of the corporate charter as a "grant," to be narrowly construed, with its concomitant doctrine of ultra vires, has merely resulted in gobbledegook $^{27}$ drafting of omnibus charters, with fantastic enumeration of purposes and powers, plus tongue-in-cheek clauses that all the powers are also meant to be pur-

${ }^{24}$ Wis. STAT. $\$$ I 80.45 (I) (c) (1955). ${ }^{25} I d . \$ \times 80.45(2)$.

${ }^{20} \mathrm{Id}$. $\$ \mathrm{I80.04}$.

${ }^{27}$ ELvin R. LATtT, InTroduction to Business Associations II (I95I): "Thus . . you will not find the lawyer drafting 'to own and operate a drugstore' but more likely something like this gobbledegook in the drafting of which the writer once participated:

"To manufacture, import, export, buy, sell, use, distribute, transport, store and otherwise deal in and use drugs, drug sundries, medicines, patent medicines, prescriptions, medical formulae, proprietary articles, chemicals, extracts, tinctures, pomades, ointments, liniments, physicians' and hospital supplies and equipment, surgical instruments and equipment, scientific apparatus, dental goods, rubber goods, toilet articles and preparations, perfumes, cosmetics, paints, chemicals, oils, dye stuffs, brushes, electric goods and supplies, music, musical supplies, cameras, photographers' equipment and supplies, optical supplies, stationery, postcards, books, newspapers, magazines, periodicals, cigars, cigarettes, tobacco, smokers' supplies, candy, confectionery, soda, carbonated and aerated waters, ice cream, soft drinks refreshments, pastry, foods and food products, jewelry, hardware, leather goods, clocks, watches, cutlery, art goods, dry goods, notions, novelties, small wares, and all articles and other merchandise of every kind, naturc and description, and all cartons, containers, kegs, barrels, jars, bottles, boxes, tins, packages and other materials or substances used in the packing, wrapping, boxing, preserving or marketing thereof; to operate, maintain or conduct warehouses and retail or wholesale stores, shops and stands in the United States or elsewhere for the purpose of storing, selling or otherwise dealing in any of the articles and other merchandise hereinbefore mentioned.'

"A paragraph like the foregoing is frequently just the beginning of the purpose and objects clause." 
poses, plus clauses to counteract interpretations of eiusdem generis and exclusio alterius. All this boiler plate is meant, or hoped, virtually to create an all-purpose corpoartion. The time, therefore, has come to acknowledge this and, at least when the parties so desire, permit the creation of an all-purpose corporation, with a short charter enumerating not what the corporation is to do, but what, if anything, it is not to do. ${ }^{28}$

Presumably, then, the charter of a Wisconsin corporation can now simply state: "The purpose of the corporation is to engage in any lawful activity within the purpose for which corporations may be organized under the Business Corporation Law." True, one will not know what a corporation's activities are by looking at its charter'; but realistically; even today, if one wants to know what kind of business activities the corporation is pursuing, he must look beyond the charter. And there is nothing in the authorization of an all-purpose corporation which prevents or even renders more difficult the appropriate solution of the problem of the rights and remedies of investors who, by misrepresentation, are induced to invest their money for one business purpose and find it applied quite differently.

A recent California enactment gives a novel twist to the idea of the informative charter by requiring the charter to state the corporate purposes, "including a statement in a separate paragraph identifying the specific business in which the corporation proposes primarily initially to engage." 29 There seems, then, still to be some life in the "quäint notion of an informative charter, even though it discloses to the 'early reader of' the charter only what the corporation is going to start out to do, and, to the later teader, only what it originally started out to do.

Novel, in the sense that it sounds a new note in modern legislative drafting, although state corporation statutes and even state constitutions at the turn of the century revealed a similar spirit, is the Texas resort to the "purpose" provisions of the business corporation statute to strike at one aspect of business activity that is usually thought of as being in the antitrust area-i.e., forbidding a corporation in one line of activity to engage in a specific allied line that would result in a stifling combination. The new Texas statute forbids a corporation to combine stock-raising with slaughtering or subsequent processing, or oil-producing with oil pipe-lining. ${ }^{30}$

II

\section{Corporate Powers and Related Matters}

\section{x. New enumerated powers}

Recent legislation shows a decided trend away from that distrust of corporate enterprise which manifested itself in extremely strict views of ultra vires and in

${ }^{28}$ Contrast the philosophy of the new Texas statute requiring that "the purposes shall be fuily stated in the articles of incorporation." TEx. Bus. CoRp. ACr art. 2.0x-A (1956). With this encouragement, the Texas lawyer should scale new heights of exuberant drafting. But Texas has long had a sui generis attitude toward corporate powers and purposes. See the now-displaced Texas Corporation Law. TEx. Rev. Civ. Stat. art. I302 (1948).

${ }^{20}$ Cal. Corp. Code $\S 30 \mathrm{O}(\mathrm{b})$.

${ }^{30} \mathrm{TEx}$. Bus. CoRp. ACr art. 2.0I-B(3) (1956). The qualifications in the probibition indicatc, however, that the welfare of local oil interests were not overlooked. 
doctrines that always created a doubt when a corporation contemplated the employment of new techniques in keeping with the advancing science (or is it an art?) of management. The result has been a constant lengthening of the list of enumerated powers granted to corporations in state statutes.

\section{Donations}

Although expresss authorizations of donations for charitable, religious, scientific, educational, or other beneficient purposes have occasionally appeared in corporation statutes for a long time, ${ }^{31}$ it is worthy of note that every jurisdiction that has substantially revised its corporation statutes since World War. $\mathrm{II}^{32}$ has inserted a provision of this sort. All of them except Kentucky ${ }^{33}$ expressly authorize "charitable" donations, and all but the District of Columbia specifically sanction "education" as an appropriate object of corporate largesse; ${ }^{34}$ a majority, however, shy away from likewise voicing approbation of religious donations. ${ }^{35}$. Similar donative authorization has also been reflected in the statutes of a number of states which have not, in general, substantially revised their corporation statutes. ${ }^{36}$ Most of these statutory provisions, however, seem to leave an opening for a conservative court still to require a fairly direct benefit to the corporation; ${ }^{37}$ one cannot count always on the liberality and breadth of vision revealed in A.P. Smith Mfg. Co.v. Barlow..$^{38}$

\section{Wartime powers}

"A noteworthy sidelight on our troublesome times is cast by the adoption in several jurisdictions of the Model Act provision conferring power on a corporation, whatever be its business, to transact any lawful business in time of war and in aid of the United States in prosecution of the war. ${ }^{39}$ Until recent times, such a provision, although not unknown, ${ }^{40}$ was very rare.

\section{Fringe benefits}

The new statutory revisions have also evinced an inclination expressly to authorize,

${ }^{31}$ See Bell, Corporation Support of Education: Legal Basis, 38 A.B.A.J. 119 (1952), for a list of jurisdictions.

${ }^{32}$ California, District of Columbia, Florida, Kentucky, Maryland, North Carolina, Ohio, North Dakota, Oklahoma, Oregon, Texas, Virginia, and Wisconsin.

${ }^{33} \mathrm{KY}$. REV. Stat. \$ 27I-X25 (1955).

${ }^{36}$ D.C. CODE ANN. $\S 29-904$ (Supp. 1956).

${ }^{35}$ E.g. California, District of Columbia, Florida, North Dakota, Ohio, Oklahoma, Oregon, and Texas. Model Business Corporation Act $\S 4(\mathrm{~m})$, however, authorizes religious donations.

${ }^{80}$ Sec de Capriles \& Garrett, Legality of Corporate Support to Education: A Survey of Current Developments, 38 A.B.A.J. 209 (1952). Not to be overlooked is the authors' point that there may be a constitutional problem with respect to corporations formed before the statute was amended to permit the donation in question. The authors' view that the problem is not serious, however, is sound.

${ }^{37} \mathrm{Sec}$, however, the Oklahoma statute which authorizes donations that will "benefit or contribute to the corporate or public interest." OKLA. STat. tit. 18 , $\$ 9$ (195I). (Emphasis added.)

${ }^{88} 13$ N.J. 145, 98 A.2d 58I (1953).

${ }^{30}$ Moder Business Corporation Act $\$ 4(\mathrm{n})$, followed by D.C. Code Ann. $\$ 29-904$ (Supp. I955); N.D. Laws 1957, c. I02, $\S 4$-13; ORE. REv. Stat. $\$ 57.030$ (I4) (Supp. I955); TEX. Bus. Corp. Act, art. 2.02(15) (1956); Wis. StaT. \$ I80.04(13) (1955).

so Apparently the idea grew out of World War I experience, as shown by a similar provision in the Illinois General Corporation Act of I919, Ill. Laws I919, at 318. 
probably out of excess of caution, ${ }^{41}$ the power to pay pensions and to establish plans for pensions, profit-sharing, stock bonuses, and other incentives for directors, officers, and employees-particularly in those jurisdictions that have closely followed the 1953 draft of the Model Act. ${ }^{42}$ Again, there is no complete novelty here: a Pennsylvania statutory provision authorizing corporate pensions ${ }^{43}$ dates apparently from 1893 , at least in so far as it relates to "employees"; and the New Jersey statutory provision authorizing employee stock-acquisition plans and profit-sharing, ${ }^{44}$ dating from r920, is called to mind by the famous American Tobacco Co. litigation. ${ }^{45}$

\section{Partnership arrangements}

The new North Carolina statute permits corporations virtually to enter into partnership arrangements, even if that involves sharing control with others or delegating control to others. ${ }^{46}$ The novelty of this provision lies largely in its specific attention to the troublesome corporate-partnership problem. Possibly the provision long existing in some state statutes which has permitted a corporation to acquire shares and "interests in" partnerships and other forms of enterprise could be stretched to reach the same end."7

\section{Guaranties}

The power conferred by one recent statutory revision in somewhat unusual phraseology, "to enter into contracts of guaranty or suretyship or make other financial arrangement for the benefit of its personnel or customers or suppliers," ${ }^{38}$ apparently is based on the fear that, in the light of the decisions of that state at least, mere general guaranty-authorizing language is not satisfactory. ${ }^{49}$

\section{III}

\section{Some Minutiae About Directors and Managementro}

\section{Service on nonresident directors}

Beginning with Indiana in $1945,{ }^{51}$ several jurisdictions have subjected nonresident directors of domestic corporations to the process of local courts in suits by or against

${ }^{41}$ See Bleicken, Corporate Contributions to Charities: The Modern Rule, 38 A.B.A.J. 999, 1001 (1952).

${ }^{2}$ N.D. Laws 1957, c. I02, $\$$ 4-16; Ore. Rev. Stat. $\$ 57.030(16)$ (Supp. 1955); TeX. Bus. Corp. Act art. 2.02(17) (1956); VA. Code ANN. $\$$ 13.I-3(o) (Supp. 1956); cf. Model Business Corporation Acr $\$ 4(\mathrm{p})$.

18 PA. STAT. tit. I5, § 2852-316 (1936).

"N.J. REV. STAT. \$ 14:9-1 (1937).

${ }^{46}$ Rogers v. Guaranty Trust Co., 288 U.S. 123 (1933).

${ }^{10}$ N.C. GEN. STAT. \$ 55-I7 (Supp. 1955).

47 See Chicago Bar Ass'n, Illinois Business Corporation Act Annotated 36 (2d cd. 1947), commenting on section $5(\mathrm{~g})$ of that Act, which goes back to the 1933 revision.

${ }^{48}$ N.C. GeN. STAT. \$ 55-17 (b)(3) (Supp. 1955).

"Dery few corporation statutes specifically mention the power to guarantec, and the few that do seem to be aimed at guaranteeing securities of other corporations and enterprises. Fortunately, in many jurisdictions, a sound body of common law is fully adequate to business needs.

${ }^{50}$ The major trends and developments relating to directors and management are to be found in other articles in this symposium.

${ }^{61}$ IND. ANN. STAT. $\$ 2-804$ b (1946). 
the corporation to which the director is a "proper" or "necessary" party" or "relating to" 63 or "arising out of or founded upon" the action of a domestic corporation, with provision for substituted service upon the secretary of state or the corporation's service-of-process agent..$^{54}$ Such statutory provisions insure that at least one jurisdiction can entertain a derivative suit against directors in that awkward situation where the corporation, although a necessary party defendant, cannot be "found" in the same jurisdiction where the real defendants are..$^{55}$ A statutory provision of this kind, which has been held not to violate due process, ${ }^{56}$ would also be helpful in meeting the difficulty presented by those decisions holding that in a suit to compel payment of dividends, the directors are necessary parties. ${ }^{57}$ On compelling dividends, incidentally, the new North Carolina statute doubly clinches the matter by permitting a suit for that purpose to be brought against the corporation, with or without joining the directors. ${ }^{58}$ A somewhat similar problem arose a few years ago when a suit to. compel a corporation to cancel options allegedly given without consideration was. dismissed because of failure to join the optionees, who were held to be necessary parties defendants; ${ }^{59}$ but a recent statutory provision in one state at least would. handle the problem by making the suit quasi in rem, with the "situs" of the option. at the corporation's registered office, with the alternative of joining the optionees in an action in personam. ${ }^{60}$

\section{Directors-by-proxy}

A I955 Arkansas enactment ${ }^{01}$ permitting a director, if the bylaws so authorize, to vote by proxy, with the limitation that no director can be proxy-holder for more than one other director, is unique enough to warrant notice, although the idea is:

82 N.C. Gen. Stat. $\$ 55-33$ (Supp. 1955).

Es S.C. CODE $\$ 10-432.1$ (1952).

"Mrch. Comp. Laws $\$ 450.701$ (Supp. 1956).

EE A partial solution of the diffculty can sometimes be achieved in federal courts through a combination of diversity citizenship, the venue statute which permits a derivative suit to be brought in any judicial: district where the corporations could have sued the directors, 62 STAT. 936 (1948), 28 U.S.C. \$ I40r (x952), and the extraterritorial-service-of-process statute permitting process to be served on the corporation in any district where it is organized or licensed to do business or is doing business. 62 STAT. 945 (1948), 28 U.S.C. $\$ 1695$ (1952). But the diversity requirement itself can cause jurisdictional troublefor the plaintiff, although this has been somewhat alleviated by the recent case of Smith v. Sperling, 354 . U.S. 9I (1957).

"io Wagenberg v. Charleston Wood Products, Inc., I22 F. Supp. 745 (E.D. S.C. I954).

${ }^{67}$ See Schuckman v. Rubenstein, I64 F.2d 952 (6th Cir. 1947) (applying Ohio law); Southern Mills. v. Armstrong, 223 N.C. 495, 27 S.E.2d 28I (I943). See I5 A.L.R.2d II24 (r954) for other decisions. pro and con.

${ }^{E}$ N.C. Gen. STAT. $\$ 55-50(k)$ (Supp. 1955).

${ }^{60}$ Elster v. American Airlines, Inc., 106 A.2d 202 (Del. Ch. 1954) (plaintiff was given an opportunity. to bring in optional defendants, if he could serve them).

${ }^{\circ 0}$ N.C. Gen. Stat. $\$ \$ 55-45$ (d) (Supp. I955).

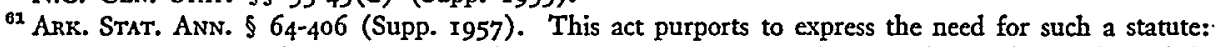
"Inasmuch as it appears that many small domestic corporations may be severely handicapped in their operations by the inability of directors to attend meetings of the board because of illness or absence....." Ark. Acts I955, No. 83 . 
not entirely without statutory precedent. ${ }^{62}$ Unlike stockholders, who are by statute everywhere permitted to vote by proxy, whatever be the common-law rule, orthodox doctrine requires directors to participate in meetings in person. ${ }^{63}$ Even aside from the fact that directors are a representative body, their number and geographical dispersal do not create the same pressing need for proxy voting as do the number and geographical dispersal of the shareholders.

\section{Directors' control of compensation}

Despite the prevalence of stock-option compensation and the many comments that can be found in its favor as a method of attracting executive talent and spurring it on to even greater managerial achievements, an undercurrent of hostility to the practice, probably based on a suspicion of "too much of a good thing," occasionally comes to the surface in judicial decisions. Particularly significant was a series of Delaware decisions in $1952,{ }^{64}$ which adopted as their method of assault the classical "no-consideration" device for undermining contracts. These decisions led to a 1953 Delaware statutory amendment that "in the absence of fraud in the transaction, the judgment of the directors as to the consideration for the issuance of such rights or options and the sufficiency thereof shall be conclusive." ${ }^{\text {"65 }}$ Similar legislation has since been enacted in Montana, New York, Virginia, and Pennsylvania. ${ }^{60}$ It remains to be seen, however, whether a court, while conceding the finality of the directors' good faith judgment "as to consideration or its sufficiency," will still take it upon itself to inquire into "the very existence of consideration" judicial nimbleness. Incidentally, recent statutory provisions dealing specifically with the granting of stock options to management and employees show divergent views as to the necessity of shareholders' vote-a divergency that perhaps, again, reflects some apprehension of the possibility of abuses in this method of compensation. ${ }^{68}$

Novel, less for dealing with directors' adverse interest ${ }^{69}$ than for singling out self-voted compensation, are recent enactments in Wisconsin, Ohio, and Illinois which

${ }^{2}$ See LA. REv. STAT. tit. 12, $\$ 35$ F (1950), going back to 1928 , but which requires an authorizing charter clause.

${ }^{63}$ Henry W. Ballentine, Corporations $\times 31$ (rev. ed. 1946 ).

${ }^{64}$ Kerbs v. California Eastern Airways, Inc., 33 Del. Ch. 69, 90 A.2d 652 (Sup. Ct. 1952); Gottlicb v. Heyden Chemical Corp., 33 Del. Ch. 82, 90 A.2d 660 (Sup. Ct. x952). Cf. Kaufman v. Shoenberg, 33 Del. Ch. 21r, 91 A.2d 786 (Ch. 1952).

${ }^{65}$ Det. CODE ANN. tit. 8, \$ 157 (Supp. r956).

${ }^{\circ 6}$ Mont. Rev. Codes Ann. $\$$ 15-1801 (1955); N.Y. Stock Law $\$ 69 ;$ Va. Code ANn. $\$ 13 \cdot 1-17$ (Supp. r956); PA. Stat. Anv. tit. I5, \$ 2852-612 (Supp. 1957).

${ }^{67}$ See Framkel v. Donovan, I20 A.2d. 3 II, 316 (Del. Ch. 1956). See also Elster v. American Airlines, Inc., I28 A.2d 801, 807 (Del. Ch. I957): ". . . the critical question remuins that of whether or not consideration for the options existed as of the time they were granted. . .."

${ }^{68}$ Compare Model Business Corporation Act $\$$ I8A; Cozo. Rev. Stat. Ann. $\$ 31-2-18$ (1953); N.C. Gen. Stat. \$55-45 (Supp. 1955); VA. Code Anv. \$ 13.1-I7 (Supp. 1956); wvith OHo Rev. Code $\$$ 170r.17 (Page Supp. 1956) (amended in 1955 to make it clear that shareholder's vote is not necessary); PA. Stat. Ann. tit. I5, \$ 2852-612 (Supp. 1957) (amended in 1957 to eliminate stockholder's vote requirement).

${ }^{80}$ The California corporation statute of I93I led the way in this area. Sce CAL. Corp. Code $\$ 820$, which has been little changed since I93I. 
eliminate adverse interest as a technical defect and, presumably, will force attention to be focused on the really crucial matter-viz., the reasonableness of the compensation. ${ }^{70}$ The new North Carolina statute sets as a standard of reasonableness for selfvoted salaries "what would be paid for such services at arm's length under competitive conditions."71

A Wisconsin statutory provision is directed to a problem particularly contemporary in view of fringe-benefit practices and inflation: Must new plans look only to the future? What about present pensionees caught by inflation? The Wisconsin statute authorizes directors to pay pensions and other benefits to directors, officers, and employees and to their estates, families, dependents, or beneficiaries on account of or for prior services rendered. ${ }^{72}$ To the extent that the power is used to readjust pensions and similar payments to reflect changing price levels or to avoid arguments of invalidity of newly-adopted pension plans based in part on prior service of existing employees, the provision should find clear sailing ahead. One may speculate, however, as to the ingenuity that the Wisconsin courts will display should overreaching arouse their hostility to the payments.

\section{Directors' power to mortgage and sell}

Particularly in view of statutes requiring a shareholders' vote for the sale of all of a corporation's assets, there is always the danger that a court will announce that a general mortgage of all of its assets, being a potential disposition in any event and perhaps a present transfer under the "title" theory of mortgages, requires a shareholders' vote. ${ }^{73}$ Yet, the giving of security is a normal incident of borrowing, which traditionally is within the managerial sphere of directors. A few recent statutes, therefore, have settled the matter by specifically giving the mortgaging power to directors, free of any necessity for a shareholders' vote, unless the charter or the bylaws adopted by the shareholders otherwise provide. ${ }^{74}$ Likewise, a number of recent statutes, either by following the language of the Model Act-which, in turn, mirrors the Illinois Corporation Act of I933-in making a distinction between sales of all assets in the regular course of business and those outside the regular course of business, ${ }^{75}$ or by different language with the same end in view, ${ }^{76}$ permit the directors to sell all corporate assets in certain designated situations where any good cause to be served by a shareholders' vote requirement would be more than counterbalanced by the trouble and risk involved.

- ${ }^{70}$ Wrs. Stat. $\$ 180.31$ (1955) (aimed, no doubt, at Stoiber v. Miller Brewing Co., 257 Wis. 13, 42 N.W.2d 144 (1950)); Ohio Rev. Code ANN. § I70r.6o (Page Supp. 1956); Ill. Rev. Stat. c. 32, $\S 157.33$ (r955), as amended, Ill. Laws 1957, S.B. 266.

71 N.C. GEN. STAT. $\$ 55-30$ (Supp. 1955).

72 WIs. STAT. $\$$ I80.3I (1955).

${ }^{73}$ See Greene v. Reconstruction Finance Corp., 24 F. Supp. I8I (D. Mass. 1938).

${ }^{7}$ N.C. Gen. Stat. $\$ 55_{-112}$ (Supp. 1955); Tex. Bus. Corp. ACt art. 5.09 (1956), as amended, Tex. Laws 1957, S.B. 129; VA. Code ANn. \$ I3.I-77 (Supp. 1956).

${ }^{75}$ This would include nearly all of the recently-enacted corporation statutes. Cf. Model Business CORPORATTON ACT $\$ 73$.

${ }^{70}$ N.C. GEN. STAT. $\$ 55-112$ (b) (Supp. 1955). 
Distributions to Shareholders

\section{Accounting concepts}

Any remarks about dividends and other corporate distributions inevitably run into accounting concepts, but since other articles in this symposium are specifically devoted to these matters, there is no occasion at this point to more than reaffirm that recent corporation statute revisions, taking their cue largely from the Model Act, ${ }^{77}$ have broken some new ground in clarifying the significance and incidents of earned surplus, revaluation surplus, other capital surplus, treasury shares, reserves, and, occasionally, reorganization surplus and subsidiaries' stock dividends. ${ }^{78} \mathrm{Al}$ though the new corporation statutes are constantly pushing into new accounting areas, much of the pioneering along this line probably must be ascribed to the Ohio statutory revision of the late I920's. ${ }^{79}$

\section{Free-wheeling dividends}

The significant novelties in corporate legislation are sometimes so concealed that only the most painstaking analysis will reveal them. An outstanding example of this is one phase of the dividend provisions ${ }^{80}$ of the Model Act and of the statutes of the jurisdictions following that Act.

A quick reading of the Model Act would lead one to think: "I see that by section forty cash dividends can, in general, ${ }^{81}$ be paid only out of earned surplus; well, that's a sound, conservative position; true, I see something in the next section about 'distributions in partial liquidation,' but that's another matter."

A second look at Model Act sections forty and forty-one would reveal that arrearages on cumulative preferred stock can be paid out of unearned surplus, which, too, is quite justifiable. But it would disclose that dividends, in general, can also be paid out of unearned surplus-only, they must be called "distributions in partial liquidation," and certain safeguards must be observed. Thus, dividends cannot be paid if the corporation is insolvent or if this would put the preferred shares under water, liquidation-wise; the recipients must be told that it is a distribution in partial liquidation; and unless the charter dispenses with the requirement, the distribution must be authorized by a two-thirds stockholders' vote. So far so good. Realistically, it is a partial liquidation when dividends are paid to shareholders out of anything but profits, current or accumulated. So far, nothing particularly revolutionary is involved-and it is a definite improvement over the laws of most jurisdictions.

But a closer reading reveals the novelty-and the joker. "The board of directors of a corporation may, from time to time, distribute to its shareholders in partial

${ }^{77}$ See, e.g., Wis. Stat. $\$ \$ 180.02,180.38,180.385,180.61$ (1955).

${ }^{78}$ See N.C. Gen. Stat. \$ 55-49(k)(I) (Supp. 1955).

${ }^{70}$ I12 Ohio Laws 25 (1927), as amended, 113 Ohio Laws 433 (1929).

80 The basic provisions are MODEl Business Corporation ACT $\$ \$ 40,4 \mathrm{r}$; relevant also are $i d$. $\$ \$ 5$, $2,63,64$.

${ }^{81}$ For the point under discussion, the "wasting asset" and other exceptions are immaterial. 
liquidation, out of stated capital or capital surplus of the corporation, a portion of its assets, in cash or property. ..." 82 Combine that with an "appropriate" charter clause, in reality written by management, dispensing with the necessity of a stockholders' vote to authorize the distribution, ${ }^{83}$ and the result is this: If management wants it this way, dividends can be paid out of capital, if they are labeled distributions in partial liquidation, even if the corporation is losing money, unless it is facing creditor-insolvency or what may be called senior-shares-insolvency. ${ }^{84}$

In short, this permission of free-wheeling dividends does away with that venerable cornerstone safeguard in corporate law: legal capital, however phrased-e.g., "stated capital," "capital stock," etc. This is the farthest north ever reached, anywhere in the world, it would seem, in a legal system for business units of limited liability. One may grant that the evolution of American law has been in that direction, considering both the frequently-permitted payments of dividends out of any surplus, including surplus arising from reduction of legal capital and the generally prevailing permission to reduce capital by mere stockholders' action, without veto rights of creditors-unless the creditors contract for it-and without necessity of judicial sanction, as required in England. Still, at least lip-service has always been paid to the capital concept as a cushion of sorts-reflecting, perhaps, some guilt feeling on the part of the statutory draftsmen in the various jurisdictions who carved out the capitalreduction loophole. This has been true even in those jurisdictions permitting "nimble dividends"-dividends out of current earnings, despite impairment of capital-since such disbursements are most likely made in periods of good health and in at least some jurisdictions must be accompanied by additional safeguards. ${ }^{85}$

The Model Act might well have addressed the matter more directly and have stated as follows: "Subject to such restrictions as may be stated in the charter, dividends can be paid irrespective of existence of profits or surplus or capital impairment, unless the payment would make the corporation insolvent in the equity sense or reduce its net assets below the liquidation priority of any class of shares senior to the recipients, but shareholders must be so informed when receiving dividends from sources other than earned surplus."

Recent statutory revisions in North Dakota, Oregon, and Wisconsin have fol-

${ }^{82}$ Model Business Corporation Act $\$ 4 \mathrm{I}$. (Emphasis added.)

${ }^{83}$ See id. $\$ 4 \mathrm{r}(\mathrm{b})$ : "No such distribution shall be made unless the articles of incorporation so provide or such distribution is authorized by the affirmative vote of the holders of at least two-thirds of the outstanding shares of each class whether or not entitled to vote thereon by the provisions of incorporation of the corporation."

"Incidentally, diverse tests are adopted in the Model Act for creditor insolvency and for senior-sharesinsolvency. For the former, the test of insolvency is merely the equity test, or inability to pay debts as they become due in the usual course of business. Model Business Corporation Act $\$ 2(n)$. For the latter, the test is whether the company's net assets (assets over debts) would fall below the preferred stock's priority in voluntary liquidation. Id. $\$ 4 \mathrm{I}(\mathrm{d})$. Since senior shares are not likely to "become due," the equity test is not feasible with respect to them, and the balance-sheet test is the only alternative. But that is no reason for not employing the balance-sheet test as an additional safeguard for creditors against free-wheeling dividends unrestricted by "capital" concepts. Cf. N.C. Gen. Srat. \$55-50(d)(2) (Supp. 1955); MD. ANN. CODE art. 23, \$33(d)(2) (195I).

${ }_{85}$ E.g., N.C. Gen. Stat. $\$ 55-50$ (c)(I)(2) (Supp. I955); OkLa. Stat, tit. I8 \$ 132(a)(3) (I95I). 
lowed the Model Act in the free-wheeling pattern for dividend distribution, ${ }^{80}$ but the District of Columbia, Texas, and Virginia, generally close followers of the Model Act in their revisions, have refused to leave this opening. Indeed, the new Texas statute shows a commendable concern for the reduction-surplus loophole, specifying that dividends from such a surplus, unlike dividends from any other lawful sources, must be authorized by a two-thirds vote of all classes of shareholders, even by ordinarily nonvoting classes. ${ }^{87}$ This can afford additional protection to senior shares, although per se it does not afford much creditor protection. But the new statute then goes on to provide that if the corporation becomes insolvent, the directors voting for such dividends, or for stock repurchases from this source, will be liable to the corporation for the disbursements for the purpose of discharging "creditor claims which existed at the time such payments were made or which were incurred within thirty (30) days after notice of the reduction of stated capital had been filed," to the extent that such claims have not been fully paid after sharing in the corporate assets. ${ }^{88}$

\section{Barring old dividend claims}

Even after time-consuming research, it will not often be easy in any particular jurisdiction to determine whether the statute of limitations has run against declared but unpaid dividends. ${ }^{89}$ Does the statute start running when the dividend becomes payable, or only upon demand and refusal? Is the answer to be reached by sheer logical deduction from the rule (or fiction?) that declaration of the dividend creates a debtor-creditor relation? Or is it a "trust" relation? Which statute applies-that relating to trusts, implied contracts, obligations in writing for the payment of money, or some other ${ }^{30}$ A recent Wisconsin statutory provision attempts to cope with the problem by cutting off the shareholder's rights to declared dividends and other distributions if the amount declared as a dividend or authorized in some other distribution remains unclaimed for six years from the date specified for payment. This is to be done "upon declaration of forfeiture made by resolution of the board of directors," provided that six months' notice be given prior to the effective date of the forfeiture in substantially the same manner as prescribed for giving notice of shareholders' meetings-i.e., mailed to shareholder at his address as it appears on the corporate records. ${ }^{92}$ A recent Ohio statutory provision is somewhat similar, but it makes the lapse of time per se bar the claim, without the need of a forfeiture declaration by the directors. ${ }^{93}$ A different legislative solution has been reached in some other jurisdictions by making dividends unclaimed after a prescribed period payable (1955).

${ }^{86}$ N.D. Laws I957, c. 102, \& 41; Ore. Rev. Stat. \$55-221 (Supp. 1955); Wis. Stat. \& 180.39

${ }_{87}$ Tex. Bus. CoRp. ACT art. 2.40-A(3) (I956).

${ }^{88}$ Id., art. 2.4I-A(6).

${ }^{80}$ See Note, The Lost Shareholder, 62 Harv. L. Rev. 295 (1948).

${ }^{\text {Bo }}$ See generally id.; II FLETCHER, op. cit. supra note $16, \$ 5370$ (1932).

${ }^{01}$ WIs. STAT. $\$ 180.395$ (1955).

${ }^{D 2} I d . \$ 180.24$.

${ }^{93}$ Ohio. Rev. Code Ans. $\$$ I jor.34 (Page Supp. 1956). 
to the state, there subject to either the claims of the owner if he shows up ${ }^{94}$-which at least relieves the corporation of liability to shareholders, although it does not get to keep the dividend-or escheat.95

\section{Strengthening or clarifying the insolvency limitation on dividends}

In an effort to do something about the gradual decay of legal capital as at least a modicum of protection for creditors, a phenomenon already mentioned, Oklahoma's new statute forbids dividends "when, after payment of such dividend, the net assets of the corporation shall not equal an amount in excess of one-fourth $(1 / 4)$ its debts and liabilities." Although this is not entirely a new idea, ${ }^{97}$ so rare is an attempt in that direction nowadays that the effort perhaps merits classification as a novelty.

Several jurisdictions have, for several decades, required that the corporation meet both tests of insolvency-the so-called bankruptcy and equity tests-before paying dividends. ${ }^{98}$ That still leaves some question as to the basis of valuation for the bankruptcy test. One recent statute prescribes the test of "fair present value" of the assets, ${ }^{99}$ apparently in the belief that at least this much protection for creditors is justified, even though this may impose a conservative dividend policy on the directors of a debt-loaded corporation.

\section{Charter clauses cutting down preferred stock's dividend sources}

One recent North Carolina dividend novelty is to forbid charter clauses that cut down the sources of dividends otherwise lawfully available for preferred stock. ${ }^{100}$ Its purpose is to prevent the coercion of the preferred shareholders into a disadvantageous recapitalization bargain by persuading them that the payment of dividends to them is legally impossible, despite current earnings, unless they concur in a plan which embodies a capital reduction wiping out the capital impairment that under the charter provisions is preventing the payment of dividends. ${ }^{101}$ It is always a hard policy choice legislatively to restrict freedom of contract, but it must be recognized that the charter, especially in publicly-held corporations, ${ }^{102}$ is hardly a bargained contract.

\section{Protection of noncumulative dividends}

Another recent North Carolina novelty is the attempt to protect that "waif of the stock exchanges," noncumulative preferred stock, against dividend shenanigans by

“E.g., N.C. Gen. Stat. \$ II6-22 (1952).

- E.g., Mrch. CoMrp. LAws $\$ \$ 567.15,567.22$ (1948).

"OkLa. Stat. tit. 18, 5 133(3) (1951).

ot See Car. Corp. CODE $\$ 1908$, which is aimed at the dissipation of capital by disbursements following its reduction. See also the required assets-liabilities ratio in the North Carolina corporation statute before July I, 1957. N.C. GEN. STAT. \$55-II6 (1950).

"E.g., CAL. CoRp. Code $\$$ I5OI; ILL. REv. STAT. $\$ 157.4$ I (1955). These statutes go back to the early 1930's.

$\because$ N.C. GEN. Stat. $\$ 55-50$ (c) (Supp. I955). $\quad{ }^{100}$ Id. $\$ 55-50($ b).

${ }^{10 x}$ See Barrett v. Denver Tramways Corp., 53 F. Supp. I98 (D. Del. 1943), affd, I46 F.2d 70I (3d Cir. 1944).

${ }^{103}$ For legislative recognition of the wider role of contract in close corporations, see N.C. GEN. STAT. 73 (b) (Supp. 1955). 
recognizing in its favor a "dividend credit," as defined ${ }^{103}$ in the new statute. Briefly, a "dividend credit" arises in favor of noncumulative preferred shares for those years when less dividends were paid to those shares than could have been paid to them out of earnings; and so long as such dividend credit exists, no dividend is to be paid to junior shares. ${ }^{104}$ In a sense, then, even noncumulative preferred is made cumulative-if-earned, charter provisions notwithstanding. Arguably, why be concerned about noncumulative preferred stock? It is never issued-at least as far as the writer has been able to ascertain-except in reorganizations, as a result of the bargaining and evaluating that takes place in that process. If plain noncumulative stock is what the interested parties have bargained for, why give them cumulative-ifearned stock? The answer is that no one in his right mind consciously bargains for directors'-whim-noncumulative stock-which is what out-and-out noncumulative preferred stock boils down to, short of "fraud" (whatever that is), and if an enterprise is so shaky that on reorganization it cannot issue an honest preferred stock, let it reorganize with plain common stock.

\section{Compulsory dividends}

Also novel is the new North Carolina statute's mildly-compulsory dividend provision, ${ }^{105}$ although it has some claim of legitimate parentage in prior legislation in that state and elsewhere. ${ }^{106}$ In substance, it requires a corporation, on written demand of twenty per cent of the stockholders, or of a class of stockholders in some situations, to pay out one-third of its annual net profits in dividends. Its purpose is to make it harder for the dominant majority in a close corporation successfully to work the traditional squeeze play, wherein one of the squeezors' strategems is to pay no dividends, despite good earnings, year after year, during which time the squeezors are getting their returns through self-voted salaries, until finally the exhausted squeezee sells out in desperation at a price satisfactory to the squeezors. The enactment under discussion is quite complex and technical, probably creating as many new problems as it solves and reflecting difficult policy choices. Obviously, the twenty-per cent-shareholder requirement renders the statute virtually inapplicable to publiclyheld corporations, but the squeeze play is not much of a problem in those corporations.

\section{Repurchase of shares}

The "enabling" spirit of twentieth-century corporation statutes is well illustrated in the evolution of permission to a corporation to purchase its own shares. Its course can be seen in the swing from prohibition of purchase under an ultra vires analysisin some jurisdictions at least, following the English precedent-to permissive pur-

${ }^{103} I d$. \$ $55-(2)(5)$.

${ }^{105} I d . \S 55-50(\mathrm{c})$.

${ }^{204} I d$. $\$ 55-40(\mathrm{c})$.

${ }^{100}$ The former North Carolina corporation statute had provided that the directors must, by January 3 if no other date is fixed, declare $a$ dividend of all the accumulated profits over and above what is reserved for working capital. N.C. GeN. STat. \$ 55-115 (1950). New Mexico has a similar dividend provision. N.M. Stat. ANN. \$ 51-3-16 (1953). Both of these provisions were patterned after one that appeared in New Jersey's famous corporation law of 1896 , but which was subsequently eliminated. 
chase from surplus, and thence to purchase even out of capital in a few favored situations where apparently there were deemed to be overriding considerations of corporate convenience. Ohio led the way in its corporation statutes revision of the I920's, permitting purchases regardless of surplus in order to redeem redeemable shares, compromise claims, perform repurchase obligation to employees, resell to employees, eliminate fractional shares, resell to others shares repurchased under contract with shareholders, and buy out dissenters entitled to being bought out. ${ }^{107}$ Recent legislative activity has added purchases under a contract with a shareholder to buy his share at his death, ${ }^{108}$ purchases by open-end investment companies (variously phrased), ${ }_{2}^{109}$ and purchases in partial liquidation of the corporation. ${ }^{110}$ Increasingly, then, the creditor's cushion afforded by legal "capital" is being discarded as a mechanism for creditor protection. ${ }^{111}$

Some recent cross-currents against the stream of pure "enablingism" are, however, discernible. In North Carolina and Wisconsin, the repurchase of shares is forbidden if it would reduce the corporation's net assets below the liquidation priority of shares having preferential rights on liquidation over the class of shares purchased; and although it is not entirely clear, in Wisconsin even junior preferred shares may receive this protection on the purchase of senior preferred shares.112 The District of Columbia's statutory revision, ${ }^{113}$ in adopting a similar restriction on the redemption or purchase of redeemable shares, reveals ancestry in this respect in the California General Corporation Law of I93I, which shows that the basic idea is not a recent one. Subject to certain enumerated exceptions, North Carolina and Texas forbid the repurchase of junior shares when the corporation is in default in the payment of dividends on its senior shares. ${ }^{114}$ The idea is sound; except for certain transactions where there is an overriding policy, as in the enumerated favored exceptions-e.g., to pay dissenters, eliminate fractional shares, compromise claims, etc.a corporation has no business using its funds to make this type of return of corporate assets to junior stockholders when there are arrearages on its preferred shares. North Carolina carries the idea one step further: even redeemable preferred shares are not to be purchased otherwise than by redemption-or for such favored corporate purposes as have already been mentioned-if there are dividend arrearages on those preferred shares, unless the shareholders of that class or the market are seasonably informed of the corporation's intention to make such purchases. ${ }^{115}$ The idea here

${ }^{107} 113$ Ohio Laws 437 (1929).

${ }^{108}$ UTAH CODE ANN. $\$$ I6-2-I6 (1953).

100 Tex. Bus. CoRp. ACT art. 2.03-G (1956); N.C. Gen. Stat. 5 55-52(a)(5) (Supp. 1955); VA. CODE ANN. \$ 13.1-4 (Supp. 1956).

${ }^{110}$ N.H. REv. Stat. ANN. $\$ 294: 28$ (1955).

111 But see OHro Rev. Code ANN. $\$$ I701.35 (Page Supp. 1956), for a return to a capital-impairment prohibition-except that the "stated capital" thus safeguarded is that which remains after the reduction effectuated by the purchase, as to which see $i d$. $\$$ I70I.3I.

113 N.C. GeN. Stat. $\$ 55-52$ (e)(3) (Supp. I955); Wis. Stat. $\$$ I80.385(r)(b) (r955).

${ }^{113}$ D.C. CODE ANN. $\$ 29-904$ a (Supp. 1956).

116 N.C. Gen. Stat. \$ 55-52(e)(4) (Supp. 1955); Tex. Bus. Corp. Act art. 203-C (I956).

${ }^{118}$ N.C. GEN. StaT. \$ 55-52(f) (Supp. I955). 
is to discourage a corporate practice that is not unknown: depressing the price of the redeemable preferred stock by passing dividends and then buying up the stock at less than its redemption price.

Besides the equity-sense insolvency limitation that is placed on the repurchase of shares, even in the favored instances of permitted repurchase out of capital, several jurisdictions have recently adopted the additional bankruptcy test of insolvency as a further safeguard.116

A novel attempt to foreclose favoritism in the repurchase of a corporation's own shares is seen in the North Carolina statutory provision that, except with respect to transactions in the specially-favored categories of the kind already mentioned, shares must be purchased only pro rata, or on an organized stock exchange, or upon the approval of the holders of a majority of the shares exclusive of those held by the selling shareholder, or in connection with regulated stabilizing operations. ${ }^{117} \mathrm{~A}$ Wisconsin statutory provision, too, represents a commendable effort to prescribe the freezing of earned surplus applied to the repurchase of shares and then to state the transactions which may thaw out the surplus so frozen. ${ }^{118}$

The recent statutory revisions have also shown a tendency to abandon some restrictions, such as a required charter clause or a shareholders' vote, if shares are to be repurchased out of other than earned surplus, but this is merely refining an idea that emerged in the revisions of the r930's.

One still, however, observes no statutory provision aimed at curbing that questionable practice of the Great Depression: the corporation's purchase of its own shares to bolster a falling market in those shares, sometimes in an effort to bail out the management.

\section{V}

Diverse Matters About Shareholders and Their Holdings

\section{Stock certificate recitals}

The laws of a number of jurisdictions have, for some time, required stock certificates to contain a statement of the rights of the different classes or series of shares, if the shares are divided into classes or series. The increasing complexity in the capital structure of many corporations has resulted in longer and longer statements, particularly with respect to convertible preferred stock and sinking-fund provisions. Since the size of stock certificates does not expand accordingly, being set partly by tradition and partly by the rules of the stock exchanges for listed shares -eight inches by twelve inches is the New York Stock Exchange standard-the result has been that the print is getting smaller and smaller. (Incidentally, what with margins, stock-transfer legend, and reserved space, the actual space for text on

${ }^{110}$ MD. ANN. Code art. 23, $\$ 28$ (c) (1951); N.C. Gen. STAr. $\$ 55-52$ (c)(2) (Supp. 1955); TeX. Bus. Corp. ACT art. 203-F (1956). Each of these states employs the standard of "fair value" of the assets in applying this test.

${ }^{112}$ N.C. Gen. Stat. \$55-52(c) (Supp. 1955).

${ }^{118}$ WIs. STAT. $\$ 180.385$ (I)(c) (I955). 
the back of a stock certificate is not much over six inches by five inches.) Indeed, the print is microscopic on occasions. The writer recently saw one certificate with an estimated $\mathrm{x} 7,000$ words of stock-provision text on the reverse side. Some state statutes have, for some time, permitted a summary in lieu of the full text, but no lawyer is happy with a summary. Recent legislation has met the problem by permitting the stock certificate to state the designation of the various classes or series of shares and then to state that the corporation will furnish the shareholder, without charge, a full statement of the stock characteristics as set forth in the charter. ${ }^{119}$

\section{Stock certificates with old signatures or seals}

In active stocks, large numbers of certificates bearing the signatures of the present corporate officers will be delivered to the transfer agent, who may have a large portion of them on hand even after those corporate officers have ceased to be such. To avoid the expense of scrapping these certificates and the trouble of signing new ones, nearly all recent substantial revisions of corporation statutes have provided that certificates with old signatures can still be issued as if the officers had not ceased to be such. ${ }^{120}$ A further Illinois refinement is aimed at avoiding a similar technical snag where the corporate seal has been affixed to stock certificates prepared for issuance, but has been changed before they are actually issued..$^{121}$

\section{Cash for fractional shares}

An Ohio statutory provision has added to the choices available to a corporation faced with issuing fractional shares: as an alternative to issuing scrip in lieu of fractional shares, the corporation may pay off the fractional shares in cash. ${ }^{122}$ Illinois followed suit in $1957 .^{123}$ It remains to be seen whether someone will attempt a minority freeze-out by a corporate recapitalization which, by decreasing the number of outstanding shares, reduces the minority freezee to ownership of less than one share, particularly under the Ohio statute where apparently the board of directors can fix the value of the fractional share.

\section{Registered shareholders with fiduciary or incomplete capacity}

The voting, transfer of shares and receipt of dividends by shareholders of record who are minors or holders in a fiduciary relation has long been a source of worry

120 FLA. Stat. $\$ 608.4 \times$ (1955); N.C. Gen. Stat. $\$ 55-57$ (Supp. 1955); N.D. Laws 1957, c. ro2, 5 20; OHIo REv. CODE ANN. $\S$ I70r.25 (Page Supp. 1956) (certificate may recite that a statement of the express terms of the shares is on file at an office of the corporation within the state or with a transfer agent); Tex. Bus. Corp. ACT art. 2-r9 (1956), as amended, Tex. Laws 1957, c. 54 (mere reference to provisions filed with the secretary of state suffices); VA. CODE ANN. $\$$ I3.I-20 (Supp. I956); WIs. STAT. $\$ 180.18$ (I955). MD. ANN. CoDE art. 23, $\$ 27$ (c) (195I) (summary of information included in a registration statement permitted to become effective under the Federal Securities Act of 1933 is acceptable).

${ }^{220}$ The recent statutory revisions in District of Columbia, Florida, Kentucky, Maryland (also former law), North Carolina, North Dakota, Ohio (also former law), Oklahoma, Oregon, Texas, Virginia, and Wisconsin embody this feature. Delaware, too, has had such a statute for some time.

${ }^{221}$ ILL. REv. STAT. C. 32, § I57.21 (1955), as amended, Ill. Laws 1957, S.B. 266.

19 Ohro Rev. Code ANN. \$ r7or.24 (Page Supp. 1956).

${ }^{128}$ ILI. REv. StAT. c. 32, 157.22 (1955), as amended, Ill. Laws I957, S.B. 266. 
to corporations, and scattered legislative recognition ${ }^{124}$ of the problem antedates even the Uniform Fiduciaries Act, section three of which relieves the corporation of the duty to inquire into possible breaches of trust in the transfer of the shares by a shareholder of record who is a fiduciary. ${ }^{125}$ Amendment to the corporation statutes of California and Ohio in r93I already had extended protection to the corporation when stock transfer or voting was by a shareholder who was a minor; and the Ohio statute went further by giving the corporation the benefit of a conclusive presumption of full capacity of the registered shareholder, absent delivery to it of a certified copy of a court order of guardianship of the shareholder. ${ }^{126}$

Recent legislative activity along these lines has developed some refinements. A New York statutory provision authorizes a corporation to treat an infant shareholder as entitled to receive dividends and other distributions, vote, give consent, give proxies, make elections, and exercise rights relating to his stock, with no right in the infant to disaffirm as against the corporation; but this protection to the corporation is mitigated by the qualification: unless the corporation has actual knowledge of the infancy. ${ }^{127}$ The recent North Carolina statute makes knowledge of minority or other incompetency or lack of authority of a representative irrelevant as far as the corporation is concerned, ${ }^{128}$ although presumably the saving graces of equity would prevent the corporation from exploiting the incompetency to its unjust enrichment. So, whatever rights a minor who repudiates the cashing of his dividend check may have against other parties, the corporation is in the clear. A recent Ohio statutory amendment goes beyond merely immunizing the corporation by specifically empowering a minor to vote his shares. ${ }^{129}$

Although the purpose of section three of the Uniform Fiduciaries Act, which dates from I922, was to relieve corporations of the risks inherent in transferring shares held by fiduciaries, the Act, since adopted in twenty-three states, has been aptly termed a conspicuous failure. ${ }^{129 a}$ In the $1940^{\prime}$ 's and 50's, Connecticut, Oklahoma, and Virginia enacted statutory provisions to free corporations of the need to inquire into the authority of fiduciaries in making transfers of stock (or other securities); ${ }^{\mathbf{1 2 0 b}}$ and the Uniform Commercial Code, recently adopted by Pennsylvania, Massachusetts, and Kentucky, would extend similar protection to corporations on security transfers other than those made by fiduciaries, particularly the revised versions of the Code enacted by Massachusetts and Kentucky. ${ }^{129 \mathrm{c}}$ Also patterned on the Uniform Com-

${ }^{126}$ See MASs. GeN. Acts Igr8, c. 68, \& 3. $\quad{ }^{105} 9$ B U.L.A. I7 (I957).

${ }^{128}$ Cal. Corp. Code $\$ 2221$; Ohto Rev. Code ANn. $\$ \$$ I701.28(D), 170x.46 (Page Supp. 1956).

${ }^{127}$ N.Y. GEN. CORP. LAW $\$ 12-a$. A 1953 Wisconsin statutory provision is substantially along these lines. WIs. STAT. $\$ \$ 180.85$, I80.85I (I955).

${ }_{123}$ N.C. GEN. STAT. \$ 55-59 (Supp. I955).

129 OnHo Rev. Code ANN. \$ I70I.46 (Page Supp. I956).

${ }^{1292}$ Conard, $A$ New Deal for Fiduciaries' Stock Transfers, 56 Mich. L. Rev. 843, 844 (1958). Professor Conard's fine study shows the inadequacy of this legislation in achieving its purpose.

${ }^{120 b}$ Conn. Gen. Stat. \$ 29IId (Supp. 1955); OKIA. Stat. tit. 18, \$ r.II8 (195I); Va. Acts 1948, c. I62, repealed Va. Acts 1956, c. $428, \$$ r.

${ }_{1290}$ P. StAT. ANN. tit. I2A, $\$ 8$ 8-401-04 (1954); Mass. ANN. LAws c. 106, $\$ \$ 8-40$ r-04 (Supp. 1958); Ky. Acts 1958, c. 77, pp. 377-80. 
mercial Code is a 1953 Wisconsin statutory provision. ${ }^{129 d}$ Moreover, three states have recently adopted the Model Fiduciaries Securities Transfer Act, ${ }^{129 \mathrm{e}}$ a product of the joint efforts of committees of the American Bar Association and the Illinois State Bar Association, which purports to simplify transfers and minimize issuers' liability in connection therewith. For a discussion of the differences, effectiveness, and potentials of these various statutes, including the national and international conflict-of-laws angles, the reader is referred to Professor Conard's excellent analysis. ${ }^{120 f}$ Finally, although not generally thought of as in the field of corporation law, the "nominee statutes," permitting some kinds of trustees to put the entrusted securities in the name of a nominee, which burst forth largely in the 1940's and 50's would seem to achieve, despite their imperfections, ${ }^{129 g}$ some degree of simplification of security transfers and some relief from breach-of-trust liabilities of corporate issuers and their transfer agents. ${ }^{120 \mathrm{~h}}$

\section{Notices to enemy shareholders}

The period under consideration produced some war-inspired corporate legislation, ${ }^{130}$ including scattered statutory provisions relating to communications and notices to shareholders who are forbidden contacts, such as enemies or near-enemies. One problem to which these provisions were directed arises from the conflict between a statutory requirement of notice to shareholders and directors relating to meetings, and the Federal Trading With the Enemy Act proscribing such notice. ${ }^{131} \mathrm{New}$ Jersey and New York in I942 and Delaware in I943, accordingly, enacted legislation which provided that any notice otherwise required is dispensed with as to persons with whom communication is forbidden by any federal law, rule, regulations, or executive order..$^{132}$ Similar action has been taken, somewhat belatedly (one hopes) in Ohio and North Carolina. ${ }^{133}$

\section{VI}

\section{Stock Transfer Restrictions}

The new Texas statute is the only legislation, recent or otherwise, that goes into any detail in the matter of stock transfer restrictions. ${ }^{134}$ The real heart of the matter, however-viz., which restrictions are and which are not reasonable-was apparently believed to be too complicated for solution by detailed statutory rules.

190d Wis. Stat. $\S 180.85$ (1955).

${ }^{1200}$ Conn. Pub. Acts I957, No. 573; Del. Laws I957, S.B. 287; Ilu. Rev. StAT. c. 32, \$\$ 439.50-57

${ }_{1200}$ Conard, supra note r2ga. See also id., Simplification of Security Transfers by Fiduciaries, 94 Trust \& Estates 835 (1955).

${ }^{1205}$ See Comment, 56 Mrch. L. Rev. 963 ( 1958 ).

1995 Citations to the statutory provisions of the forty-two states having such legislation may be found in the appendix to $i d$. at 985 -1003.

${ }^{130}$ See, e.g., supra 369 relating to wartime corporate powers.

${ }_{181} 40$ STAT. 412 (I9I7), 50 App. U.S.C. § 3C (1952).

132 Del. Code Ann. tit. 8, $\$ 230$ (1953); N.J. Rev. Stat. $§$ I:I-2.5 (Supp. 1944); N.Y. Gen. Corp. LAW 332 .

${ }_{133}$ Oho Rev. Code Ann. $\$$ I70r.43 (Page Supp. I956); N.C. Gen. Stat. $\$ 55$-I73 (Supp. I955).

${ }^{23}$ Tex. Bus. Corp. ACT art. 2.22 (I956). 
Accordingly, the express statutory authorization is stated in terms of restrictions that do not "unreasonably" restrain or prohibit transferability, or that "reasonably" define the rights of the corporation or of its shareholders to buy shares offered for transfer, or that "reasonably" define rights and obligations under buy-and-sell agreements binding on all shareholders of the class of shares in question, if the number of record shareholders of that class does not exceed twenty. The restrictions can be imposed in the bylaws as well as in the charter, thus clarifying at least one minor problem that has bothered some courts, and restrictions so imposed by the corporations must be stated on the stock certificates. (Query, does that invalidate a side agreement of the buy-sell variety, not stated in the certificates? Presumably not, as between the parties thereto; these are not restrictions imposed by the corporation. Anyhow, the statute in this respect differs little from section fifteen of the Uniform Stock Transfer Act. ${ }^{135}$ )

\section{VII}

\section{Proxies and Other Matters Relating to Voting}

\section{Proxies}

One state has recently given legislative attention to the troublesome problem of irrevocable proxies instead of leaving the matter to that somewhat complex area of agency law that is unfortunately associated with the "coupled with an interest" doctrine. A 1953 New York enactment provides that an irrevocable proxy, if it is so labeled and if it expressly purports to be irrevocable, can be held by a pledgee, a purchaser under an executory contract to buy shares, a creditor to whom the proxy is given in consideration of credit extension, or a person who gets such a proxy as part of the consideration of his contract to perform services for the corporation as an officer. ${ }^{136}$ (The irrevocability of proxies in that state is apparently limited to the situations above specified, ${ }^{137}$ which may be unduly restrictive.) A purchaser of shares without actual notice of the irrevocable proxy thus authorized, however, takes free of it, unless the irrevocability is plainly stated on the face of the stock certificate. New York had already moved somewhat in the direction of legislative recognition of irrevocability of proxies, although not too clearly, in its I929 enactment that "every proxy shall be revocable at the pleasure of the person executing it . . . but the parties to a valid pledge or to an executory contract of sale may agree in writing as to which of them shall vote the stock until the contract of pledge or sale is fully executed."138

The new North Carolina statute is unique in limiting the irrevocability of proxies to ten years, even if coupled with an interest. ${ }^{139}$ Its purpose was apparently to harmonize the time limitation to that of voting trusts ${ }^{140}$ and pooling agreements, ${ }^{141}$

${ }^{185} 6$ U.L.A. 20 (1922).

${ }^{137}$ N.Y. GEN. CORP. LAW $§$ rg.

${ }^{130}$ N.C. GEN. STAT. \$ 55-68 (Supp. 1955).

${ }^{140}$ Td. $\$ 55-72$.
${ }^{186}$ N.Y. STOCK CoRP. LAW $\$$ 47-a.

${ }^{188}$ Ibid.

${ }^{141}$ Id. \$ 55-73(a). 
the voting-trust statute in that state recognizing no exception to the ten-year limitation for the coupled-with-an-interest situation, unlike that of some other states. Apparently it was believed that ten years is long enough to tie up voting rights, especially in view of the fact that a party who needs a longer period may be in a position, under a sufficiently foresighted contract, to exert pressure upon the proxygiver to execute additional irrevocable proxies from time to time as called for by the contract, thus extending the ten-year period.

\section{Voting trusts}

A new wrinkle in voting trusts has appeared in the Florida statutory provision that seems to abandon the theory that the voting trustees have legal title to the shares. It contemplates instead that the trustees "shall not acquire the legal title to the stock but shall be vested only with the legal right and title to the voting power which is incident to the ownership of the stock."142 (A rather intriguing concept of "title.") The certificates for the shares concerned are to be tendered to the secretary of the corporation for him to note thereon the subjection of the shares to the voting agreement, which fact is to be "recorded" by him in designated corporate books, and this notation subjects purchasers of the shares to the voting trust. It appears that the intention here may have been to dispense with the common practice of registering the shares in the names of the voting trustees (the shareholder surrendering his old certificate and the trustees possessing the new one) and of the issuance by the latter of trustees' certificates; instead, the annotated stock certificates are apparently to be left in the hands of the beneficial shareholders. If the result is a "trustee" with neither legal title nor possession of the "res," this serves to remind us that it is sometimes easier to attain a specific result from a court or legislature under a reassuring false label than by sheer analytical honesty and plain talk. What this Florida statutory provision seems to come down to is that if you agree to let someone else vote your shares for ten years or less, he can do so, regardless of your change of heart. Compare the caution with which the New York statute approaches the problem semantically as one of "irrevocable proxies," limiting the irrevocability to designated situations.

A further novelty in voting trusts is found in the new North Carolina requirement that the real shareholders-the holders of the beneficial interests-are to retain their voting rights in such fundamental matters as charter amendment, bylaw amendment, capital reduction, merger, consolidation, sale of assets, and dissolution. ${ }^{143}$ The theory apparently is that the main business need for a voting trust is to assure stability in management and that for this, little more is needed than to give the voting trustees the power over choice of management.

New York requires voting trustees to keep records of certificate holders comparable to the corporation's stock books and subject to analogous rights of inspection

${ }^{162}$ FLA. STAT. $\$ 608.43$ (1955). A later amendment eliminated an ambiguity in the new theory by eliminating a reference in the statute to stock "held" by the trustees; the shares are now referred to as the "stock as described in the agreement."

${ }^{149}$ N.C. Gen. STAT. \$55-72(c) (Supp. 1955). 
by certificate holders. ${ }^{144}$ The recent North Carolina statute has a similar requirement. $^{145}$

\section{Self-voted shares}

The Model Act puts into specific statutory language a sound principle that courts probably recognize anyway ${ }^{146}$ - viz., that shares in the parent corporation owned by a subsidiary corporation are not to be voted or counted for quorum purposes, any more than are treasury shares. ${ }^{147}$ The recent statutory revisions in North Carolina, North Dakota, Oregon, Texas, and Virginia follow the Model Act in this respect. ${ }^{148}$ The famous New Jersey statute of 1896 , followed in this respect in a number of states, had already forbidden the voting "directly or indirectly" of shares of its own stock "belonging to" the corporation, language which lends itself to reaching the same result. ${ }^{149}$ Recent legislation in the District of Columbia and Wisconsin adopts this older pattern. ${ }^{150}$

Legislative concern with a corporation's voting of shares of its own stock held in a fiduciary capacity is not new. ${ }^{151}$ But the Model Act's policy choice of not permitting such shares to be voted is of recent vintage, at least in state law, ${ }^{162}$ and represents a controversial choice, followed in some statutes subsequent to the Model Act, ${ }^{153}$ rejected in others. ${ }^{154}$

\section{Pooling agreements}

Agreements for voting several blocs of shares of different shareholders as one unit have led a checkered life, ${ }^{155}$ but no statute seems to have specifically concerned itself with the problem before the recent North Carolina statute. ${ }^{156}$ This statute recognizes the validity of such agreements, if limited to ten years-to synchronize with similar limitations on the analogous voting trust-but does not contemplate that the stockholders' meeting is to be the forum for specific enforcement of the agreement. ${ }^{157}$

${ }^{244}$ N.Y. STOCK CORP. LAW $\$ 50$.

${ }^{145}$ N.C. GeN. STAT. \$ 55-72(b) (Supp. I955).

${ }^{140}$ See Italo Petroleum Corp. v. Producers Oil Corp., 20 Del. Ch. 283, 174 Atl. 276 (Ch. 1934).

${ }^{147}$ Modet. Business Corporation Act $\$ 3 \mathrm{I}$.

${ }^{148}$ N.C. Gen. Stat. $\$ 55-67$ (b) (Supp. 1955); N.D. Laws 1957, c. 102, $\$ 30$; Ore. Rev. Stat. $\S 57.170$ (Supp. 1955); Tex. Bus. CoRP. ACT art. 2.29(B) (1956); VA. CODE ANN. $\$$ 13.1-32 (Supp. 1956).

${ }_{140}$ O'Connor v. International Silver Co., 68 N.J. Eq. 67, 59 Atl. 321 (Ch. 1904), affd, 68 N.J. Eq. 680, 62 Atl. 409 (Ct. Err. \& App. 1905).

${ }^{150}$ D.C. CODE ANN. \$ 29-9II(b) (Supp. 1956); Wis. STAT. § 180.25 (1955).

${ }^{261}$ See, e.g., Ill. Rev. Stat. C. $32, \$ 157.29$ (1955); Pa. Stat. tit. 15, $\$ 2852-508$ (1936).

${ }^{159}$ Cf. 48 STAT. 186 (1933), r2 U.S.C. $\$ 6 \mathrm{x}$ ( 1952$)$ (stock in national bank held by it as sole trustee).

153 N.C. Gen. Stat. $\$ 55.67$ (b) (Supp. 1955); N.D. Laws 1957, c. 102, $\$ 30$; ORE. Rev. Stat. $\$ 57.170$ (Supp. 1955); TEX. Bus. Corp. ACT art. 2.29 (I956).

${ }_{15}$ D.C. CODE ANN. $\$ 29-9 \times 1$ (b) (Supp. 1956); Wis. STAT. $\$ 180.25$ (1955). For an intermediate position, see VA. Code ANn. $\$ 13 \cdot 1-32$ (Supp. I956).

${ }^{105}$ Compare Ringling Bros.-Barnum \& Bailey Combined Shows, Inc. v. Ringling, 29 Del. Ch. 610, 53 A.2d 44 I (Sup. Ct. 1947), with Roberts v. Whitson, I88 S.W.2d 875 (Tex. Civ. App. 1945), and authorities therein cited.

${ }^{158}$ N.C. GeN. STAT. $\$ 55-73$ (a) (Supp. x955).

${ }^{157}$ Cf. Smith v. San Francisco \& N. P. Ry. Co., 115 Cal. 584, 47 Pac. 582 (1897). 


\section{Fundamental Changes}

Other articles in this symposium will generally discuss the current tendencies in the area of fundamental corporate changes. This discussion, accordingly, is purely supplemental.

\section{Protecting the high-vote protection}

With the virtual disappearance of "vested rights" and the almost limitless presentday scope of charter amendment, a shareholder holds that bundle of rights that we call his shares virtually at sufferance; votes of others may transform that bundle into one utterly, perhaps shockingly, different. The parties to the charter contract may, therefore, want to freeze the status quo in large measure by a clause to the effect that amendments can be made only by a prescribed vote, higher than otherwise required. Perhaps such a clause cannot itself be changed by a mere majority or twothirds vote, if those are the statutory standards for charter amendments; ${ }^{158}$ but to clinch the matter, two recent statutes specify that such a clause cannot itself be changed except by the same so-prescribed higher vote. ${ }^{159}$ One of these statutes is also fortified by a similar provision with respect to changes effected by merger or consolidation, ${ }^{100}$ just to forestall evasions by resort to the Havender subterfuge. ${ }^{101}$

\section{Reorganization and federal statutes}

During the 1930's, Delaware, Maine, Maryland, New Jersey, New York, and Pennsylvania adopted statutes to synchronize state law with reorganizations under the Federal Bankruptcy Act. ${ }^{162}$ The scheme of these statutes was, in general, that pursuant to the provisions of a court-confirmed plan of reorganization, fundamental changes in the corporate structure and securities could be made, without the vote of shareholders and without dissenters' right of appraisal, by the registry of a prescribed certificate executed by court-designated representatives, such as trustees, corporate officials, and masters. The principal innovation introduced in later decades was the extension of this technique to include reorganizations pursuant to the Federal Public Utility Holding Company Act of 1935 in California, Delaware, Maine, Michigan, New Jersey, New York, Ohio, Oklahoma, and Virginia. ${ }^{163}$ Wisconsin contents itself with requiring the secretary of state and the register of deeds to file and record duly certified court orders in proceedings under the Bankruptcy

${ }^{158}$ Sellers v. Joseph Bancroft \& Sons Co., 23 Del. Ch. 13, 2 A.2d 108 (Ch. 1938).

${ }^{100}$ N.C. Gen. Stat. $\$ 55-100(b)(3)$ (Supp. 1955); VA. CODE ANN. $\$ 13.1-56$ (Supp. 1956).

${ }^{100}$ N.C. Gen. STAT. $\S 55$-I08(b) (Supp. 1955).

${ }^{101}$ Federal United Corp. v. Havender, 24 Del. Ch. 3I9, II A.2d 3 II (Sup. Ct. 1940). By the "Havender subterfuge," the writer is referring to what is probably the cleverest corporation law trick of our times, whereby the law forbidding a given charter amendment can be avoided and/or cvaded by a fake merger. Cf. Langfelder v. Universal Laboratories, Inc., I63 F.2d 804 (3d Cir. r947).

${ }^{102}$ Del. Code Ann. tit. 8, $\$ 245$ (1953); Me. Rev. Stat. AnN. c. 53, 77 (1954); MD. Ann. Code art. 23, \$7I (I951); N.J. Rev. Stat. \$ 14:I4-44 (I937); N.X. Gen. Corp. Law \$ 9-b; Pa. Stat. AnN. tit. $15, \S 2852-320$ (Supp. 1956).

${ }^{103}$ The various Delaware amendments probably served as the source. See note following DEL. CODE AnN. tit. 8, $\$ 245$ (1953). 
Act that affect charter amendments, without prescribing the effect of the procedure. ${ }^{164}$

The Oklahoma statute raises an entirely different problem when it authorizes "compromise arrangements" between categories or classes of them, to become binding upon approval by prescribed percentages if sanctioned by the court. ${ }^{105}$ One wonders whether a thus rearranged creditor might not still assert his old position on the ground that the Bankruptcy Act's reorganization provisions have superseded the state law. ${ }^{108}$

\section{Unfair fundamental changes in senior shares}

The picture here is the recapitalization plan which wipes out the many years of dividend arrearages on cumulative preferred stock, so that the wide gulf that prevents the common stock from participating in the corporation's sudden prosperity is eliminated. As Messrs. Stevens and Larson have well put it: ${ }^{107}$

That the common stockholders should enthusiastically embrace the resulting recapitalization plans, with the elimination of accrued preferred dividends and usually the sacrifice of other preferential rights by the preferred is easily understandable; what may puzzle the reader of these cases is: why is there always to be found approval also by a majority of the preferred, and, more often than not, a very large majority?

The answer seems to be that preferred stockholders ... can usually be depended upon to approve anything that is submitted in a persuasive proxy letter.

Understandably, management likes the prevalent law on the point: short of "fraud," approval by a majority of the affected class makes any question about fairness irrelevant. Not much has been done about this in recent legislation, less because of a Candidian faith in this best of all possible rules than because of two factors: (I) it is not easy to legislate on this problem without running into practical diffculties; and (2) the constituency of most state corporation law revision committees is not inclined to advocate features disliked by management. An occasional effort, direct or indirect, has, however, appeared in recent legislation.

A I95I Nebraska statutory provision authorizes an adversely affected shareholder to apply to a court to enjoin, on the grounds of "fraud or unfairness," a charter amendment altering priorities of preferred shares. ${ }^{168}$

Recent North Carolina legislation has moved more cautiously, recognizing the difficulties facing a court passing on fairness, which often ultimately boils down to a forecast of future earnings, ${ }^{169}$ particularly if under the plan, the preferred stock

${ }^{104}$ WIS. STAT. $\$ 180.56$ (1955).

${ }^{105}$ OKLA. STAT. tit. $88, \$$ I7O (I95x).

${ }^{100}$ Compare International Shoe Co. v. Pinkus, 278 U.S. 261 (1929), with Johnson v. Star, 287 U.S. 527 (1932).

${ }_{107}$ Robert S. Stevens \& Arthur Larson, Cases and Materials on the Law of Corporations 637 (2d ed. 1955).

${ }^{208}$ NeB. Rev. Stat. $\$ 2$ I-I 62 (1954). (Emphasis added.)

${ }^{109}$ A recapitalization plan can, of course, be clearly unfair on its very face, as where, for cxample, 
receives some common stock or becomes "participating" or convertible. The new North Carolina statute contains a provision forbidding clauses in the charter or elsewhere that would render current earnings unavailable for dividends to preferred shares. ${ }^{170}$ This is accompanied by statutory authorization for payment of dividends out of current earnings despite capital impairment and does away with a club with which the common stock-through its spokesman, management-can bludgeon the preferred shareholders into voting for a dubious plan. ${ }^{171}$

The North Carolina legislation has, at the same time, also made it possible for the preferred shareholders to bargain at the charter stage for a contract changeable only by a bargained high vote, which conceivably could be set so high as to make changes virtually impossible. ${ }^{172}$ It makes a novel effort, too, to put a floor under the dissenting preferred shareholders' payment-two-thirds of their liquidation priority if the common shareholders pay nothing for retaining their position in the recapitalized corporation. ${ }^{173}$ Furthermore, it extends appraisal rights to objecting holders of preferred shares with arrearages when those arrearages are being adversely affected by a "voluntary" exchange of securities pursuant to a transaction that involves no charter amendment, merger, consolidation, or similar appraisal event. ${ }^{174}$

\section{Appraisal rights}

The new Virginia statute has a meritorious provision that dissenting shareholders with appraisal rights with respect to a fundamental change-under that statute, in merger, consolidation, or sale of assets-who are unable to agree with the corporation as to the value of their shares can be made parties, wherever residing, to a judicial proceeding to determine what is due them, "as an action against their shares quasi .in rem." ${ }^{175}$ This may be preferable to such procedural alternatives as joinder of the dissenters as parties plaintiff or defendant and consolidation of scattered suits. ${ }^{176}$

The whole question of dissenters' rights to appraisal and payment needs reexamination. Too often our statutes have withheld such rights where probably needed and have conferred them in situations where not needed-automatically, for example, in mergers, regardless of whether the merger means for the dissenter a substantially different enterprise. The pattern is haphazard. Often the existence of such rights turns on the form of a transaction, rather than on its substance. Why should a merger subject the expanding entity to appraisal rights by dissenters when a

whatever be the future earning prospects, it requires the preferred stock to make all of the sacrifice and the common stock to make none, or virtually none, although such a plan was involved (and judicially upheld!) in Donahue v. Heuser, 239 S.W.2d 238 (Ky. r95I).

${ }_{170}$ N.C. Gen. StAT. $\$ 55-50$ (b) (Supp. 1955).

171 See stipra 377.

${ }^{179}$ N.C. Gen. Stat. $\$ 55^{-100(b)(3) ~(S u p p . ~ I 955) . ~}$

${ }^{173}$ N.C. GEN. STAT. $\$ 55-\mathrm{II}_{3}$ (e) (Supp. I955). Otherwise, there is the danger illustrated by Root v. York Corp., 22 Del. Ch. 35x, 50 A.2d 52 (Ch. 1946), in light of Hottenstein v. York Ice Machinery Corp., 136 F.2d 944 (3d Cir. 1943).

174 N.C. Gen. STAT. \$ 55-102 (Supp. 1955).

${ }^{175}$ VA. Code ANN. $\$$ r3.1-75, I3.1-78 (Supp. 1956).

${ }^{170}$ See Ohio Rev. Code ANn. $\$$ r7or.85 (Page Supp. 1956). 
similar expansion by acquisition of properties financed, say, by issuance of additional shares does not? Accordingly, one must view as sound the idea expressed in the 1953 New York statutory provision denying appraisal rights to shareholders of the surviving corporation in a consolidation (merger) when that event does not make the kind of fundamental changes in the dissenter's shares that would give him appraisal rights under a charter amendment. ${ }^{177}$ Further reconsideration might indicate that appraisal rights should be made to turn less on the shareholder finding himself in a different legal entity or in an expanded enterprise than on being drastically changed with respect to participation in earnings, liquidation, and control. It might also indicate that appraisal rights in a sale-of-assets situation should be granted in, and only in, a sale of assets for securities of the purchaser corporation, as one recent statute has provided, ${ }^{178}$ rather than be denied in all sales, as is the case in most jurisdictions, or be granted even in sales for cash, as appears to be the case in some others. Sale of all of a corporation's assets for the purchaser's stock is, realistically, closer to a real merger of enterprises than are some "mergers" between affiliated companies.

\section{Required notice to shareholders of appraisal rights}

The new North Carolina statute requires that when shareholders are asked to vote on specified fundamental changes which give rise to dissenters' rights of appraisalcertain charter amendments, mergers, consolidations, etc.-they must be notified of these rights. ${ }^{179}$ This idea is new in state corporation law, although it has been a familiar feature of the Securities Exchange Act of 1934 and regulations thereunder. ${ }^{180}$ Amendments in 1957 to the Pennsylvania statute reflect the same policy. ${ }^{\mathbf{1 8 1}}$ Wisely or not, however, the North Carolina legislation expressly states that failure to include the notice does not invalidate the transaction in question, but gives the shareholder, unless he voted for the transaction, a year within which to make demand on the corporation for such damages as he may have suffered from his failure to receive notice. It remains to be seen whether North Carolina corporations will omit the notice and take their chances; the Pennsylvania lawyer, faced with statutory silence on the effect of failure to give notice, would be less inclined so to advise.

\section{Tie-in with SEC-supervised proxies}

The new Virginia statute permits a merger or consolidation to be approved by a majority of the shares of each class of shares, when the right to vote by classes exists, instead of by the "more than two-thirds" vote normally required, if the Securities and Exchange Commission "exercises jurisdiction over the proxy statement" for the pertinent shareholders' meeting. ${ }^{182}$ The idea is a good one not only because SEC supervision affords some assurance that the shareholders are being

${ }^{177}$ N.Y. STOCK CORP. LAW $\$ 87$.

${ }^{178}$ N.C. GEN. STAT. \$ 55-113 (Supp. 1955).

${ }^{170} I d . ~ \$ \S 55-100,55-108,55-112,55-x \times 8$.

${ }^{180}{ }_{17}$ C.F.R. \$ $240.14 a-9$, schedule $\times 4 A$, item 2 (1949).

${ }^{181}$ PA. Stat. ANN. tit. 15, \$\$2852-31r, 2852-902 (Supp. 1957).

${ }^{182} V_{\text {A. CODE ANN. }}$ 13.T-70 (Supp. 1956). 
adequately informed of the matter under consideration, but also because, in the main, the publicly-held corporations within the federal proxy rules are the very ones in which it is sometimes difficult to get a two-thirds vote from the scattered and lethargic shareholders. For the latter reason, the Virginia statute might well have relaxed its requirement that, despite the majority vote of each class, there be approval of more than two-thirds of the total outstanding shares for a merger or consolidation. Incidentally, the thus permitted lower class vote for mergers and consolidations that fall within the SEC proxy regulations is not extended by the Virginia statute to charter amendments; however, it would be farfetched to see here a further occasion for resort to the Havender subterfuge for using the merger device to amend the charter.

\section{Sale of assets}

A relocation of a corporation's business is often accompanied by a change in the corporate entity as, say, by the formation of a new corporation-perhaps in another state-and the transfer of its assets to the new corporation for securities of the latter. Such a transaction is within the literal language of those statutes that give appraisal rights to dissenters on a sale of assets, but hardly within their spirit. ${ }^{183}$ Accordingly, a I957 Pennsylvania statutory provision quite logically exempts a sale of assets made for the purpose of relocating the business from the necessity of either a shareholders' vote or shareholders' appraisal rights. ${ }^{184}$ The same end, with resultant out-of-state reincorporation, can be achieved by forming a subsidiary under the law of the new state and merging the parent into the subsidiary, if there exists a favorable combination of merger statutes-i.e., the statutes of both states permitting merger with a foreign corporation, plus a statute of the parent state dispensing with appraisal rights in the case of a merger into a wholly-owned subsidiary. Of course, if the relocation sale of assets is accompanied by other fundamental changes in rights of shareholders, especially as between classes, the problem is not that simple.

The Model Act has given further impetus in recent state statutes to the now venerable Ilinois legislation with respect to the necessity for a shareholders' vote on a sale of all assets, differentiating between sales in and out of the ordinary course of business-a distinction reflected also in recent New York amendments and, although by a slightly different approach, in the new North Carolina statute. ${ }^{185}$

\section{Mergers with foreign corporations and with subsidiaries}

Since the California corporation statute revision of I93x, authorization for a domestic corporation to merge or consolidate with a foreign corporation enjoying

${ }^{183}$ As a series of New York cases have recognized. See Matter of Hake, 285 App. Div. 316,136 N.Y.S.2d 817 (4th Dep't 1955); Petition of Avard, I44 N.Y.S.2d 204 (Sup. Ct. 1955); Rudel v. Eberhard Faber Pencil Co., 2 Misc. 957, 146 N.Y.S.2d 498 (Sup. Ct. 1955).

${ }^{183}$ PA. Stat. ANN. tit. 15, $\$ 2852-31$ I (Supp. I955).

${ }^{186}$ N.Y. STOCK CORP. LAW $\$ 20 ;$ N.C. Gen. STAT. $\$ 55-112$ (Supp. 1955). Cf. Model Business CORPORATtON ACT $\$ \$ 72-74$. 
similar authorization has become familiar. All recent statutory revisions have incorporated this feature. ${ }^{186}$

The comparatively ancient vintage of the New York short form of merger of a wholly-owned subsidiary into a parent corporation robs the revisions of the 1950's in that direction of complete novelty. The outstanding characteristics of this latter legislation are rather the simplification of procedures for such a merger-frequently, all that is needed is a resolution of the board of directors of the parent corporation, without a shareholders' vote ${ }^{187}$-and, perhaps even more important, the denial of dissenting shareholders' appraisal rights. ${ }^{188}$ Even the standard longer form of merger under the Model Act and its followers, however, quite properly gives no appraisal right to dissenting shareholders of the surviving corporation which itself had held all the stock of the other constituent corporations, where the merger thus amounts to but a simple absorption of the subsidiaries. ${ }^{189}$ A new wrinkle in this parent-subsidiary merger situation is introduced by section 68A of the Model Act's 1957 list of Revisions and Optional Sections, which permits employment of the short form of merger when the parent owns ninety-five per cent of the stock of the subsidiary, with appraisal rights for the dissenting shareholders of the subsidiary, ${ }^{200}$ but not for those of the parent.

\section{Dissolution and newly-discovered assets}

One difficulty in corporation law long has been: What should be done with newly-discovered assets after purportedly complete liquidation and after the filing of the last papers that officially put an end to corporate existence? Statutes that prolong corporate life for two or three years for purposes of suit afford no satisfactory answer. The new North Carolina statute would recognize corporate life indefinitely, whenever necessary to administer newly-discovered assets: the corporation can sue in its name, acting through its last board of directors, however reduced in numbers, or through its last officers; and the thus still-vital corporation can re-establish its

${ }^{188}$ The list includes not only the states that have completely altered the basic patterns of their old corporation statutes, but many other states as well: California, District of Columbia, Florida, Illinois, Kentucky, Maryland, Michigan, Minnesota, Missouri, North Carolina, North Dakota, Ohio, Oklahoma, Oregon, Texas, Virginia, Wisconsin, and others.

${ }_{187}$ D.C. Code ANN. $\$ 29-927$ h (Supp. 1956); MD. ANn. Code art. 23, \$63 (1951); N.D. Laws 1957, c. 102, $\$ 72 ;$ Ohio Rev. CODE ANN. $\$ 1701.84$ (Page Supp. 1956); VA. Code ANN. $\$ 13.1-76$ (Supp. 1956); WIs. STAT. $\$ 180.685$ (I955).

${ }^{188}$ N.D. Laws 1957, c. I02, §75; Ohro Rev. CODE ANN. $\$$ 1701.84 (Page Supp. 1956); VA. CodB Anv. $\$ 13.1-76$ (Supp. 1956). Under D.C. CODE ANn. $\$ \$ 29-927 n, 29-927$ i (Supp. 1956), the same result is apparently reached by requiring a dissenting stockholder to file his objection prior to or at the time of the shareholders' meeting, and in the short form of merger, there is no meeting. And in Maryland, the cash-to-dissenters statutory provision does not apply to shareholders of the surviving corporation unless the merger changes their contract rights-which need not be the case where wholly-owned subsidiaries are merged into the parent. MD. ANN. CODE art. 23, \$69 (r95 $\mathrm{r}$ ).

${ }^{189}$ N.C. Gen. Stat. $\$ 55-113$ (i) (Supp. I955); N.D. Laws, c. I02, $\$ 75$; OrE. Rev. StaT. $\S 57.490(6)$ (Supp. 1955); Tex. Bus. Corp. Act art. 5.12-F (1956); Wis. Stat. $180.69(6)$ (I955); cf. Modez Business Corporation ACT $\S 7$. The District of Columbia's new corporation statute, although modeled after the Model Act, omits this feature.

${ }^{200}$ The new North Dakota Business Corporation Act of 1957 follows this Model Act pattern. N.D. Laws 1957, c. 102, $\$ 72,75$. 
board and officers if it so desires. ${ }^{191}$ A r 957 Pennsylvania statutory provision looks in the same direction. ${ }^{192}$

\section{ro. Change in "entity" and abatement of criminal proceedings}

Statutes relating to merger, consolidation, and dissolution typically state that pending actions or proceedings by or against the corporation do not abate by virtue of the disappearance or death of the "entity" and that liabilities and obligations continue. Nevertheless, it is by no means clear whether a court will discover in the statutes a legislative intention that criminal proceedings and liability fall within the scope of this language. ${ }^{193}$ If not, corporate death terminates criminal proceedings and liability. At least one of the new statutory revisions, however, makes it clear that criminal proceedings, as well as civil ones, are not terminated by dissolution or disappearance in a merger. ${ }^{194}$

\section{Restated multi-amendment charters}

To work with a charter that has gone through, say, a dozen amendments is an exasperating experience. Modern legislation has sought to meet the problem by expressly authorizing a charter amendment to consolidate the original charter and all prior amendments, plus any other contemporaneous amendments then also being made, into a restated charter. Although one such statute antedates the 1940 's, ${ }^{195}$ the late I940's and I950's is the period which has seen the most widespread adoption of this legislation. ${ }^{196}$ In some jurisdictions, the point is handled briefly by simply including it in the list of expressly permitted charter amendments; ${ }^{197}$ but a 1957 Illinois refinement requires the restated charter to be reproduced in full in the notice of meeting. ${ }^{108}$ Many lawyers would probably advise such a notice in any event; but one still may speculate as to what is the restated charter if the shareholders believe that they are merely voting on the formality of consolidating the scattered terms of their existing charter and yet the restated charter as reproduced in the notice is different. Is the latter, then, only prima facie the restated charter? If so, why not let the directors restate the charter, with prima facie effectiveness? North Carolina so provides, with the alternative of a full-fledged amendment procedure, if that is the course chosen. ${ }^{199}$

${ }^{201}$ N.C. Gen. Stat. $§ 55-114$ (Supp. I955).

${ }^{103}$ PA. Stat. ANN. tit. 15, § $2852-1$ II I (Supp. r957).

${ }^{103} \mathrm{Cf}$. United States v. Union Carbide and Carbon Corp., $230 \mathrm{~F} .2 \mathrm{~d} 646$ (1oth Cir. 1956), cert. denied, 35 I U.S. 939 (I956); United States v. Line Material Co., 202 F.2d 929 (6th Cir. r953); United States v. Maryland State Licensed Beverage Ass'n, 138 F. Supp. 685 (D. Md. 1956).

${ }^{104}$ N.C. Gen. STAT. $\$ 55-1 \mathrm{r}_{4}$ (Supp. 1955).

${ }^{105}$ OHIo REv. Code ANN. $\$$ 170r.72 (Page Supp. r956). Apparently even prior thereto, one or two states tacitly recognized restated charters by accepting them for filing and certification. P-H CoRP. NEws (Jan. 28, r952).

${ }^{200}$ Thus, in this period: California, Colorado, Delaware, Illinois, Indiana, Maine, Maryland, New York, North Carolina, North Dakota, Texas, Virginia, and Wisconsin.

${ }^{107}$ E.g. VA. Code ANN. $\S 13 . I-56$ (Supp. 1956); cf. N.C. Gen. Stat. $\$$ 55-105(e) (Supp. 1955).

${ }^{208}$ IlL. Rev. Stat. c. 32, $\$ 157.52$ (1955), as amended, Ill. Laws x957, S.B. 266.

${ }^{100}$ N.C. Gen. STAT. $\$$ 55-105 (Supp. 1955). 
A recent Texas technical refinement ${ }^{200}$ makes it clear that the text of the restated charter may include such changes as are then being additionally introduced, as distinguished from a mere consolidation text, and follows through with synchronizing technical elaborations. It is the kind of blueprint the office lawyer likes to see when he is working out a transaction, although one suspects that the bar manages satisfactorily under something less elaborate. ${ }^{201}$

In any case, authorization for a restated charter in the law of the state of incorporation does not necessarily do away with the customary requirements of submitting certified copies of the charter and all amendments (including this onel) when the corporation seeks official permission to do business in another state.

\section{IX}

\section{Foreign Corporations}

\section{Doings classified as not doing business}

A notable feature of the Model Act and of nearly all corporation statutes which have undergone radical revision since $195^{\circ}$ has been the inclusion of a formidable list of acts that are expressly stated therein not to constitute "doing business" locally by a foreign corporation. ${ }^{202}$ The basic idea is not new. For a long time, some jurisdictions have expressly excluded purely interstate transactions, as to which there were, perhaps, constitutional doubts. Others have long excluded the making of local loans and the taking of local property as security or in payment of such loans, ${ }^{203}$ or at least the taking of mortgages on local properties. ${ }^{204}$ Still other scattered exclusions antedating the I940's are local solicitations of orders through salesmen; ${ }^{205}$ mail order transactions; ${ }^{206}$ local installation of equipment by the outside seller corporation; ${ }^{207}$ holding directors' or shareholders' meetings locally; ${ }^{208}$ ownership of goods in local warehouses operated by residents or qualified corporations and local deliveries of those goods pursuant to out-of-state contracts; ${ }^{209}$ voting the stock held by foreign corporations in local corporations and, in relation thereto, participation in management and control. ${ }^{210}$ Sometimes, however, the exemption has still carried with it one consequence of "doing business": it has subjected the foreign corporation to local suits arising out of the activity in question. ${ }^{211}$

New additions, largely stemming from the Model Act, include: maintaining and defending suits and effecting settlements; maintaining bank accounts; maintaining

${ }^{200}$ Tex. Bus. Corp. ACT art. 4.07 (1956).

201 Cf. VA. CODE ANN. \$ I3.1-55(p), and 13.1-56(c) (Supp. 1956).

202 See Legislative Note, 32 WAsh. L. Rev. 204 (1957). Cf. MOdeL Business Corporation ACt $\$ 99$.

${ }^{203}$ E.g., ARIZ. Rev. Stat. ANN. \$ 10-485 (1956); S.D. Code $\$$ II.2102 (1939); Wis. Stat. $\$$ I80.801 (1955).

${ }_{201}$ KAN. Gen. Stat. ANN. \$ $17-507$ (1949).

${ }^{205}$ Dex. CODE ANN. tit. 8, \$ 343 (1953).

200 Ibid.

${ }^{207}$ Ibid; Oho Rev. Stat. ANN. 1703.02 (Page Supp. 1956).

${ }^{208}$ N.Y. GEN. CoRP. LAW $\$ 223$ (in so far as concerns maintenance of suits based on such activities).

${ }^{200}$ TenN. Code ANN. $\$ 48-918$ (1955).

210 Tex. Rev. Civ. Stat. art. I533a (1948).

${ }^{211}$ E.g., WIs. STaT. $\$ 180.801$ (1955). 
stock transfer offices or agencies; effecting sales through independent contractors; and conducting isolated transactions. ${ }^{212}$ Texas has recently added the exercising of powers of executors, administrators, or trustees with respect to a nonresident's estate, if the activities do not otherwise constitute doing business; it also has added investing, through out-of-state transactions, in Texas nonoperating mineral interests and doing various acts incidental to such ownership. ${ }^{213}$ An occasional follower of the Model Act, too, goes beyond that Act in inducing foreign capital to invest locally without incurring full "doing business" legal risks, sometimes with limitations that have an eye on some measure of competitive protection of the local lending. industry. ${ }^{214}$

\section{Expanded jurisdiction of local courts}

Even before the International Shoe case, ${ }^{215}$ the legislatures of Maryland and Vermont apparently had concluded that local jurisdiction over a foreign corporation for the purposes of suit was justified as a legitimate interest of the local state in the protection of its residents, even though the corporation was not locally "doing business" under the constitutional law decisions, and so could not be viewed as: being "present in the state" or as having "entered" the state and "consented" to suit under its laws. ${ }^{216}$ The subjection of a foreign corporation to a local suit arising out of the local commission of a tort or the breach of a contract made or to be performed locally, to the damage of a local resident, was not deemed by those legislatures to be so arbitrary, capricious, oppressive, irrational, or whimsical as to violate the requirements of "due process." As was to be expected after the International Shoe case, with its apparent repudiation of the "doing business" test in favor of a "fairness and reason" test that would seem basic in any due process determination, courts upheld this legislation. ${ }^{217}$ A novel 1955 North Carolina statutory provision went even further: It apparently operated on the theory that if a company enjoys the benefits of a local market for its product, one of the headaches that not unreasonably can be linked to that benefit is subjection to local suits in favor of local residents damaged by that product. Accordingly, it provided, in addition to the local tort and contract features, comparable to those of the Maryland and Vermont statutes, that local jurisdiction in favor of local interests could be asserted in an action against a foreign corporation that grew out of the production, manufacture, or distribution of goods by the foreign corporation with the expectation that the goods were to be used in North Carolina, regardless of how or where produced or marketed. ${ }^{218}$ This,

${ }^{212}$ E.g., Tex. Laws 1957, c. 54, $\$$ 4, amending Tex. Bus. Corp. Act art. 8.0x (1956).

${ }^{213}$ Ibid.

214 See N.C. Gen. Stat. $\$ 55-13$ I (b)(6) (Supp. 1955); Tex. Bus. Corp. Act art. 8.or(I2) and (13) (1956).

${ }_{215}$ International Shoe Co. v. Washington, 326 U.S. 3 Io (I945).

${ }^{210} \mathrm{MD}$. ANN. CoDe art. 23, $\$ 88$ (d) (195 I); VT. STAT. $\$ 1562$ (1947).

${ }^{217}$ Johns v. Bay State Abrasive Products Co., 89 F. Supp. 654 (D. Md. 1950); Compania de Astral, S.A. v. Boston Metals Co., 205 Md. 237, roy A.2d 357 (1954); Smyth v. Twin State Improvement Corp., II6 Vt. 569,80 A.2d 664 (195I).

218 N.C. Gen. STAT. $\$ 55-38.1$ (Supp. 1955) (this particular feature of the new corporation statute was not postponed in effectiveness until July $I, 1957$, as was the rest of that statute). 
however, apparently went too far for the jurisdictional "due process" outlook of the courts that have considered it, at least as applied to the cases before them. ${ }^{210}$ Another paragraph of this same enactment would base local jurisdiction on repeated solicitations of local orders by mail or otherwise, and it remains to be seen whether this, as well, is too much for the prevailing judicial notions of due process.

Another innovative feature of the recent North Carolina legislation in this area is this: It would subject a foreign parent corporation to local suit through service of process on its local subsidiary corporation, but only in those situations where the parent itself is liable for the subsidiary's obligation. ${ }^{220}$ For example, the parent's liability might arise from the thinness of the equity capital of the subsidiary or from directing the subsidiary's patent infringements or other torts. ${ }^{221}$ Maintenance of local suits against a foreign parent on causes of action so limited is not without judicial precedent. ${ }^{222}$ (This is not to be confused, however, with the broader and more dubious proposition that a foreign corporation is doing business locally if its subsidiary, especially a wholly-owned subsidiary, operates locally ${ }^{223}$-although it is by no means certain that a statute could not go even that far, ${ }^{224}$ at least as applied to causes of action in favor of local residents growing out of local activities of the subsidiary.) If a court were to follow a purely mechanistic separate-entity theory of corporations and narrowly interpret the International Shoe case, it could, of course, pronounce this provision unconstitutional on the ground that it is the subsidiary, not the parent, which

${ }^{219}$ Erlanger Mills, Inc. v. Cohoes Fibre Mills, 239 F.2d 502 (4th Cir. 1956); Putman v. T'riangle Publications, Inc., 245 N.C. 432, 96 S.E.2d 445 (1957). See also Walker v. Ballantine \& Sons, 149 F. Supp. 379 (M.D. N.C. I957). There is something to be said for the decision in the Erlanger case, since the defendant manufacturer had done nothing to cultivate the North Carolina markct; he simply had sold in New York to a customer who came in to buy. The Triangle and Ballantine cases, however, involved defendants who were systematically cultivating that market. The Triangle case becomes cven more questionable when viewed in the light of a recent Supreme Court decision. McGee v. International Life Ins. Co., 355 U.S. 220 (1957); Note, 7 Duke L.J. 135, 139 n. 26 (1958).

The aftermath of this is interesting. Because of these adverse decisions, the General Statutes Commission moved to delete the constitutionally-offensive section, and one of its members, who was at the time serving in the legislature, introduced a bill to that end. The Judiciary Committec of the Scnate, however, which is largely composed of lawyers, opposed the bill on the ground that the provision, despite judicial hostility thereto, was a good one and might still win favorable recognition in the courts. (Reported orally to the writer by one of the members of the Committee.) Thus, the courts appear to be at odds with (one may reasonably infer) the lawyers of North Carolina.

Judge Sobelof, who wrote the opinion in the Erlanger case, rationalizes his position again in Jurisdiction of State Courts over Non-Residents in Our Federal System, 43 Cornell L. Q. 196 (I957). For what appears to this writer's perhaps biased vision a successful rebuttal, see Cardozo, The Reach of the Legislattre and the Grasp of Jurisdiction, id. at 210.

${ }_{220}$ N.C. Gen. Stat. \$55-38.I (b) (Supp. I955).

221 See, e.g., Certain-Teed Products Corp. v. Wallinger, 89 F.2d 427, 436 (4th Cir. 1937).

${ }^{223}$ Industrial Research Corp. v. General Motors Corp., 29 F.2d 263 (N.D. Ohio 1928). Cf. Mazzotti v. Rainey, $3 \mathrm{I}$ Del. Ch. $447,77 \mathrm{A.2d} 67$ (Ch. 1950), critically analyzed in Note, 6o YALE L.J. 908 (195I).

${ }^{223}$ See Cannon Mfg. Co. v. Cudahy Packing Co., 267 U.S. 333 (r925).

224 Id. at 336: "The claim that jurisdiction exists is not rested upon the provisions of any state statute. . ." Consider the implication of Berkman v. Ann Lewis Shops, 246 F.2d 44 (2d Cir. 1957), for the validity of a statute that would clearly show an intention to view local business of a whollyowned subsidiary as amounting to "doing business" by the parent corporation, at least for purposes of local suits on locally-arising causes of action. 
has the "contacts" within the state. But it would be somewhat paradoxical to hold a foreign corporation not constitutionally amenable to local suit on its liability for the obligations of its wholly-owned local subsidiary and yet hold it subject to local jurisdiction through, say, the activities of a controlled "independent dealer" outlet. ${ }^{225}$ 3. Internal affairs

A further North Carolina novelty is a statutory provision that actions against foreign corporations are not to be dismissed simply because they involve "internal affairs," but that dismissal must rather turn on considerations of forum non conveniens. ${ }^{226}$ Aside from the fact that this probably reflects the unarticulated basis of most of the "internal affairs cases," one must not overlook the fact that foreign corporations are frequently local in character. ${ }^{22 \pi}$

\section{Choice of law}

One may speculate as to the purpose behind the unique 1952 Georgia enactment that the law of the state of incorporation of a domesticated foreign corporation shall govern the voting and other conditions of corporate action, the effectiveness of charter amendments, and all rights between the corporation and its shareholders and among the shareholders and the classes of shareholders. ${ }^{228}$ Offhand, it looks like a restatement of some orthodox principles of the conflict of laws. Perhaps it was simply meant to offset the other quite common statement that is found in the Georgia corporation statutes that shareholders of domesticated foreign corporations are subject to the same obligations, duties, liabilities, and disabilities as shareholders in local corporations. ${ }^{229}$

Speaking of the conflict of laws, one may also speculate as to the effect of the recent Texas variations of the Model Act with respect to the officers and directors of foreign corporations. Whereas the Model Act provides that nothing in the Act is to be construed to permit the local state to regulate the "organization or the internal affairs" of a foreign corporation authorized to transact business locally, ${ }^{230}$ the Texas counterpart refers to "the organization of such corporation, or its internal affairs not intrastate in Texas"; ${ }^{231}$ and a contemporaneous Texas variant subjects the officers and directors of such a foreign corporation to the same "duties, restrictions, penalties, and liabilities" as the officers and directors of Texas corporations. ${ }^{232}$ Query: Can these variants be construed to mean, for example, that if the directors of the foreign corporations hold their meeting in Texas and have the corporation pay a dividend in Texas that would be unlawful for a Texas corporation, they may be subject to liability, regardless of the lawfulness of the dividend in the state of incorporation? Or did this legislation have in mind primarily the pseudo-foreign corporation?

${ }^{225}$ Kahn v. Maico Co., 2x6 F.2d 233 (4th Cir. 1954); Thomas v. Hudson Sales Corp., 204 Md. 450, ro5 A.2d 225 (1954); McNeil v. Electric Storage Battery Co., Iog S.C. 326, 96 S.E. 134 (1918). Cf. S. B. MacMaster, Inc. v. Chevrolet Motor Co., 3 F.2d 469 (E.D. S.C. 1925).

${ }_{226}^{20}$ N.C. Gen. StAT. $\$ 55-133$ (Supp. I956). Cf. Note, 97 U. PA. L. Rev. 666 (1949).

${ }^{227}$ See Latty, Pseudo-Foreign Corporations, 65 YALE L.J. I37 (1955).

${ }^{228}$ GA. Code ANN. \$22-I601 (Supp. 1955). ${ }_{220}$ GA. CoDE $\$ 22-1601$ (1936).

${ }^{280}$ Model Business Corporation Act $\$ 99 . \quad{ }^{231}$ Tex. Bus. Corp. Act art. 8.0I (1956).

${ }^{232}$ Id. art. 8.02. 
(Particularly in a pseudo-foreign corporation, otherwise completely Texan, can there quite readily be "internal affairs" that are, nevertheless, "intrastate" in Texas?)

\section{The local agent}

A new twist with respect to service-of-process agents of foreign corporations appears in the new Virginia statute, which requires such an agent to be either a member of the Virginia bar or an officer or director of the foreign corporation. ${ }^{233}$ The aim of this provision is not hard to discern, but it offers no stumbling block to those organizations that make a business of serving as statutory local agents of foreign corporations: all they need do is persuade the foreign corporation to make some person in the organization's Richmond office an assistant secretary of the corporation-which, in fact, is actually the current practice. ${ }^{234}$ A 1955 Kansas statutory provision with somewhat similar objectives requires the statutory local agent to be either a local resident individual or a domestic corporation. ${ }^{235}$ Again, the nationallyoperating service organizations have merely formed wholly-owned domestic subsidiary corporations to act as statutory local agents.

\section{Revocation of authority}

Most statutes that specifically deal with the revocation for stated causes of a foreign corporation's authority to do business in the state place the power in administrative hands-usually the secretary of state. For reasons no doubt political in nature, rumors of which have even been heard in partibus infidelium, the recent Texas statute requires the revocation to be effected by the decree of a court. ${ }^{236}$

\section{Charter-filing requirement}

By a New York statutory amendment in 1954 and a Pennsylvania statutory amendment in 1957 , a foreign corporation need not file in those states a copy of its charter as a prerequisite to permission to transact business there. ${ }^{237}$ This dispensed-with formality, which has long been traditional in every other state ${ }^{238}$ and which can be something of a nuisance for a corporation with an often-amended charter, probably serves no useful practical purpose, despite theoretical arguments to the contrary, and this break with the past is probably justified.

Aside from the features above noted and some minor details, ${ }^{230}$ there is little else in the recent corporation statutes which, with respect to foreign corporations, is unfamiliar, if for no other reason than that many of the new statutes are simply lineal descendants, in this regard, of the Illinois Business Corporation Act of 1933 .

${ }_{233}$ VA. CoDE ANn. \$ 13.1-109 (Supp. 1956).

${ }^{234}$ Letters to the writer from New York headquarters of several such organizations.

${ }^{235}$ Kan. Gen. Stat. ANn. \$ I7-440I (Supp. 1955).

${ }^{230}$ TEx. Bus. Corp. Act art. 8.16 (I956).

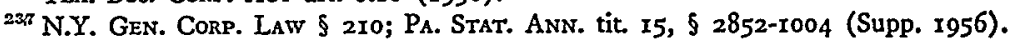

statements of more vital significance than those usually required in other states.

${ }^{238}$ Except New Hampshire, which has long been unique in imposing no such requirement, apparently with no bad effects.

${ }^{230}$ E.g., Tex. Laws 1957, c. $54, \S \mathrm{x} 2$, requiring in the application for withdrawal from the state statements of more vital significance than those usually required in other states. 